\title{
Challenges to Internationalisation of University Programmes: A Systematic Thematic Synthesis of Qualitative Research on Learner-Centred English Medium Instruction (EMI) Pedagogy
}

\author{
Murod Ismailov $1, *\left(\mathbb{D}\right.$, Thomas K. F. Chiu ${ }^{2}$, Julie Dearden ${ }^{3}$, Yukiko Yamamoto ${ }^{1}$ and Nigora Djalilova ${ }^{4}$ \\ 1 Faculty of Humanities and Social Sciences, University of Tsukuba, Tsukuba 305-8577, Japan; \\ yamamoto.yukiko.fn@u.tsukuba.ac.jp \\ 2 Department of Curriculum and Instruction, The Chinese University of Hong Kong, Ma Liu Shui, \\ Hong Kong, China; tchiu@cuhk.edu.hk \\ 3 Oxford EMI, Oxford OX2 7QL, UK; julie.dearden@oxfordemi.co.uk \\ 4 Faculty of Business Design and Informatics, Tsukuba Gakuin University, Tsukuba 305-0031, Japan; \\ djalilova@tsukuba-g.ac.jp \\ * Correspondence: ismailov.murod.gm@u.tsukuba.ac.jp
}

Citation: Ismailov, M.; Chiu, T.K.F.; Dearden, J.; Yamamoto, Y.; Djalilova, N. Challenges to Internationalisation of University Programmes: A Systematic Thematic Synthesis of Qualitative Research on Learner-Centred English Medium Instruction (EMI) Pedagogy. Sustainability 2021, 13, 12642. https:// doi.org/10.3390/su132212642

Academic Editors: Lawrence Jun Zhang and Vincent T. Greenier

Received: 27 September 2021 Accepted: 12 November 2021 Published: 16 November 2021

Publisher's Note: MDPI stays neutral with regard to jurisdictional claims in published maps and institutional affiliations.

Copyright: (c) 2021 by the authors. Licensee MDPI, Basel, Switzerland. This article is an open access article distributed under the terms and conditions of the Creative Commons Attribution (CC BY) license (https:// creativecommons.org/licenses/by/ $4.0 /)$.

\begin{abstract}
As many universities in non-Anglophone countries have committed to internationalising their academic programmes, more content courses in Arts and Sciences are being taught in English. When content courses are taught in English in a country where English is not the first language, this is called English Medium Instruction (EMI). Using specific country cases, previous studies have confirmed that an EMI course can pose many challenges to the learning of course content by students. To date, there have been few attempts to examine these challenges through a large-scale qualitative prism, which would be useful for gaining new insights in order to inform policy as well as classroom interventions. In this systematic thematic synthesis we have aimed to identify the obstacles to implementing learner-centred pedagogy in EMI tertiary programmes, focusing on student perspectives. The Critical Appraisal Skills Programme (CASP) and Consolidated Criteria for Reporting Qualitative Studies (COREQ) were used to appraise and synthesise 40 empirical articles. The articles included 1769 participants in 20 non-Anglophone countries and jurisdictions. The participants were both local and international non-native English-speaking students enrolled in EMI courses. The synthesis yielded 46 descriptive themes stratified into six analytical domains. The suggested domains are meta/linguistic, instructional, meta/cognitive, socio-cultural, affective, and institutional obstacles. They suggest that students in different regions faced quite similar challenges in their EMI courses. The challenges consist of inadequate use of English by students and lecturers, and a lack of student-centred pedagogy, particularly in teacher-student and student-student interactions. The findings of most learner-centred EMI studies revealed that the main challenges came from English comprehension (the first three suggested domains); fewer studies included factors related to the learning environment (the last three domains). This review can inform university administrators, teaching staff and researchers engaged in internationalising higher education and aid in designing appropriate EMI programmes that offer better learner-centred educational experiences.
\end{abstract}

Keywords: English Medium Instruction; learner-centred pedagogy; challenges; internationalisation; higher education; systematic thematic synthesis; qualitative research

\section{Introduction}

A recent global survey of 907 higher education (HE) institutions from 126 countries has revealed that internationalisation is becoming more common around the world [1], with more universities, especially in non-English speaking countries, prioritising the future sustainability of tertiary programmes offered in English [2]. Sustainability is becoming an important measure in assessing the long-term effectiveness of English-medium pro- 
grammes on many levels, from sustaining student learning and classroom engagement to sustaining faculty training and certification [3-6].

Defined as 'the use of the English language to teach academic subjects (other than English itself) in countries or jurisdictions in which the majority of the population's first language is not English' [7], English Medium Instruction (EMI) has been shown to be a 'growing global phenomenon' [2] as well as 'the most significant trend in educational internationalisation' [8] and it 'is developing at such a remarkable speed that it is often beyond the control of policymakers and educational researchers' [7]. In higher education, students' perspectives and experiences have been extensively researched, with findings informing professional development programmes, pedagogical interventions, and institutional planning [9-13].

To date, a few studies have explored the key outcomes of EMI for students, such as second language (L2) improvement and content learning [9-12,14]. These studies have contributed to the growing evidence that EMI may pose significant challenges to students whose first language is not English $[13,15]$. Despite such important efforts to assess and highlight the role of L2 in content learning (with some studies pointing to the contextspecific nature of implementation [16,17]), from the growing body of learner-focused literature the impression may be given that success in EMI is mainly about students linguistic needs and metalinguistic affordances. Even though there are comparatively fewer studies that address non-linguistic challenges, these demonstrate that sustaining effective EMI pedagogy might require more systematic approaches to assessing learners' needs and concerns [13].

Considering that the advantages of learner-centred pedagogy are well established within HE research [18-23], it is surprising that it has not been thoroughly addressed by EMI scholars. Researchers exploring the classroom experiences of EMI learners have focused on specific pedagogical interventions within specific geographic, disciplinary, or institutional contexts [24-27], rather than taking a comprehensive approach to exploring what makes an EMI classroom learner-centred. Perhaps for the same reason, Macaro and his colleagues in their influential review stressed the urgency of understanding the 'accommodation needs' of EMI students in order to ensure that they are effectively learning the course content [9]. In his book, Macaro [7] discusses the merits of implementing constructivist pedagogy in an EMI classroom, a process he refers to as 'quality interaction in pedagogy' and which we will further discuss in the next section.

Moreover, while numerous models, types, and characteristics of EMI [7,28-30] have been proposed, an in-depth qualitative overview of student experience beyond linguistic issues is nonetheless lacking. Exploring the pedagogical practices of lecturers that university students themselves find problematic is necessary in order to align the goals of educational internationalisation and EMI policy to student expectations. In addition, exploring the obstacles to 'learner-centred' EMI pedagogy from the perspective of learners in HE is critical for assessing the validity of existing 'success' metrics [10,11,31].

The previous reviews to which we are able to compare our study were conducted by Macaro et al. [9], Williams [32], and Kremer and Valcke [33]. The review of EMI done by Macaro et al. [9] is perhaps the most renowned study in this area, and investigated the beliefs of university teachers and students and provided evidence on whether EMI was of benefit to developing English proficiency without associated detrimental effects on content learning. Williams, on the other hand, reviewed research with reference to the South Korean context [32], while Kremer and Valcke's conference paper reviewed studies published before 2013 to examine didactic strategies employed by teachers and students in EMI classrooms [33]. Although all three studies provide useful insights into EMI research and practice, none of the papers shed light on the challenges of learner-centred EMI pedagogy from a student perspective, nor do they confine their methodologies to primary qualitative studies as we have in this study. Because of the unique systematic synthesis methodology we have adopted, the present study approaches EMI from a different perspective. 
Along with teacher-oriented EMI studies, learner-focused research has been dominated by large-scale quantitative data [7]. While quantitative data provide numerically more accurate insights into certain variables and relationships within EMI, such models often omit microfactors that may be statistically insignificant, but contextually important. Qualitative studies, on the other hand, can help lecturers, researchers, and administrators identify what learner-centred pedagogy means to students; a considerable number of such studies has indeed been conducted. These studies are often not given the attention they deserve, partly because each has been conducted within a specific context, sample or research problem. To gain a more comprehensive view of learner-centred EMI pedagogy, our aim in this study is to combine the results of multiple qualitative studies into a synthesis that offers a range of meanings, experiences, and opinions provided by student participants in a variety of EMI contexts. The depth, scope and rigour of our thematic synthesis compared to a single study may also have greater potential to influence EMI policy and inform pedagogical practice [34].

\section{Conceptual Framework and Literature Review}

\subsection{Learner-Centred Pedagogy in HE}

Learner-centred pedagogy acknowledges students' diverse needs and abilities as well as individual preferences for constructing and re-constructing content knowledge. In a learner-centred classroom, lecturers prioritise students' understanding rather than rote mastery of content subjects [35]. Although in the HE literature the term is not always used with consistent meaning [36,37], many authors have agreed that accompanying monologic lectures with interactive and innovative teaching methods improves learner engagement, critical thinking, motivation, and content learning. In addition, such conceptualisations (as shown in Table 1) have emphasised the importance of teacher-learner reciprocity, collaboration, active learning, quality feedback, intellectual challenge [18,21,23], students' responsibility for learning, clear evaluation purpose and processes $[19,21,23,38]$, engaging learners in solving real-world problems, application and demonstration of new knowledge, encouraging critical thinking $[20,23,38]$, stimulation of student interest and motivation, learner control and autonomy $[21,23,38]$, helping students construct meaning through relevant activities, lecturers' systematic alignment of teaching and learning activities [22,38], building on students' existing knowledge and skills, using dialogic teaching to support 'visible' learning [23], students and teachers as co-learners, and student-student interaction [38].

Table 1. Learner-centred pedagogical frameworks in HE contexts.

\begin{tabular}{|c|c|}
\hline $\begin{array}{c}\text { Pedagogical } \\
\text { Frameworks in HE }\end{array}$ & Key Attributes \\
\hline $\begin{array}{l}\text { Principles of good practice in higher education } \\
\text { Chickering \& Gamson (1987) [18] }\end{array}$ & $\begin{array}{ll}\text { - } & \text { Contacts among students and faculty. } \\
\text { - } & \text { Reciprocity and cooperation among students. } \\
\text { - } & \text { Prompt and quality feedback. } \\
\text { - } & \text { Optimal time on task. } \\
\text { - } & \text { High expectations. } \\
\text { Accepting diverse talents and ways of learning. }\end{array}$ \\
\hline $\begin{array}{c}\text { Keys to change toward learner-centred practice } \\
\text { Weimer (2002) [19] }\end{array}$ & $\begin{array}{l}\text { - } \quad \text { Shifting the balance of power in the classroom. } \\
\text { - } \quad \text { The function of content teaching. } \\
\text { - } \quad \text { Students' responsibility for learning. } \\
\text { - } \quad \text { Clear evaluation purpose and processes. }\end{array}$ \\
\hline $\begin{array}{l}\text { First principles of instruction } \\
\text { Merrill (2002) [20] }\end{array}$ & $\begin{array}{l}\text { - } \quad \text { Learners are engaged in solving real-world problems. } \\
\text { - New knowledge is demonstrated to the learner. } \\
\text { - New knowledge is applied by the learner. } \\
\text { - New knowledge is integrated into the learner's world. }\end{array}$ \\
\hline
\end{tabular}


Table 1. Cont.

\begin{tabular}{|c|c|}
\hline $\begin{array}{c}\text { Pedagogical } \\
\text { Frameworks in HE }\end{array}$ & Key Attributes \\
\hline $\begin{array}{l}\text { Principles of effective teaching in higher } \\
\text { education } \\
\text { Ramsden (2003) [21] }\end{array}$ & $\begin{array}{l}\text { - } \quad \text { Clear explanations of complex subjects and stimulation of student interest. } \\
\text { - } \quad \text { Concern and respect for students and student learning. } \\
\text { - } \quad \text { Appropriate assessment and feedback. } \\
\text { - } \quad \text { Ilear goals and intellectual challenge. } \\
\text { - } \quad \text { Learning from students }\end{array}$ \\
\hline $\begin{array}{c}\text { Framework of 'Constructive Alignment' } \\
\text { Biggs \& Tang (2007) [22] }\end{array}$ & $\begin{array}{l}\text { - } \quad \text { Students construct meaning through relevant activities. } \\
\text { - Teacher systematically aligns the teaching and learning activities (curriculum, } \\
\text { learning outcomes, teaching methods, assessment tasks) to each other. }\end{array}$ \\
\hline $\begin{array}{l}\text { Post-2015 standards of learner-centred } \\
\text { education } \\
\text { Schweisfurth (2015) [23] }\end{array}$ & $\begin{array}{l}\text { - } \quad \text { Engaging lessons motivating students to learn. } \\
\text { - Teacher-learner mutual respect and common ground. } \\
\text { - } \quad \text { Building on students' existing knowledge and skills. } \\
\text { - } \quad \text { Cuialogic teaching to support 'visible' learning. } \\
\text { - } \quad \text { Developing skills such as learner autonomy and critical thinking as learning } \\
\text { outcomes. } \\
\text { - Assessment processes are meaningful for those being assessed so that their learning is } \\
\text { improved by it. }\end{array}$ \\
\hline $\begin{array}{l}\text { Key elements of student-centred learning } \\
\text { Jacobs, Renandya \& Power (2016) [38] }\end{array}$ & $\begin{array}{l}\text { - Students and teachers as co-learners. } \\
\text { - } \quad \text { Student-student interaction. } \\
\text { - } \quad \text { Fearner autonomy. } \\
\text { - } \quad \text { Curricular integration. } \\
\text { - } \quad \text { Diversity. } \\
\text { - Thinking skills. } \\
\text { - } \\
\text { - } \quad \text { Learning climate. } \\
\text { - } \quad \text { Motivation. }\end{array}$ \\
\hline
\end{tabular}

\subsection{Learner-Centred Pedagogy in HE and EMI}

Previous research on students' EMI experiences suggests that many factors can affect the effectiveness of learning content in English in higher education. The existing literature on student-perceived challenges in an EMI classroom can be broadly categorised into three groups. The first group includes studies exploring macro-level factors, such as national as well as institutional policies and practices that guide the implementation of EMI and have an effect on both lecturer and student experiences. Previous studies expose gaps that exist between both national- and institutional-level EMI policies and classroom-level practices $[7,39]$. These studies highlight contextual constraints on policy implementation [29], and called for more careful curriculum evaluation to inform contextsensitive ways to implement EMI policy $[9,16]$. Other studies emphasise the importance of teacher training and qualification $[7,40]$ and institutional support for interdisciplinary as well as language instructor-content lecturer collaborations in universities that have increasing linguistically and culturally diverse student populations [41,42], as well as measures to improve students' preparedness for EMI through effective design and delivery of EAP and ESP courses [43].

The second group of studies tend to focus on meso-level factors that include a wide range of pedagogical and linguistic challenges faced by students. These challenges are often externally driven and are associated with EMI lecturers' choice of pedagogical strategies and their linguistic competence to provide an inclusive and effective EMI experience. For example, many studies focused on the impact of codeswitching, translanguaging, and bi/multilingual pedagogies on students' learning and satisfaction $[7,10,44-46]$. Studies have also provided compelling evidence regarding the multidimensionality of EMI, as seen through different kinds of assessment approaches [28], differences between content-driven 
and language-driven EMI [28], and lecturers' profiles, backgrounds, needs, and teaching styles $[27,39,47,48]$.

The third group of studies look at micro-level factors to emphasise a range of personal and externally driven issues shaping students' general satisfaction and learning outcomes in EMI courses. For example, studies have looked into the impact of linguistic and metalinguistic competence for learning success [15,25,40,49-51] and numerous other factors associated with learners' prior knowledge and schema building [52,53], previous experiences with EMI [31], skills in collaborative and cross-cultural learning [26,54], motivational and socio-emotional regulators $[11,55,56]$, and other issues.

While it is evident that the learner-centric approach can potentially increase EMI students' success and satisfaction rates, to date there have been few attempts in the EMI literature to systematically explore learner-centred pedagogy. One of the confounding factors is that in addition to content learning, EMI brings a critical ' $\mathrm{E}$ ' factor into play, that is, English. A recently proposed working definition of an EMI course [57] highlighted the critical role of language in designing and delivering content courses, by suggesting that:

"For EMI courses, the delivery of content, whole-class interaction, the learning materials, and the demonstration and assessment of learning outcomes (such as oral presentation, assignments, or tests) should be in English. Other languages may be used in a principled and limited way in specific circumstances, for example, student-to-student and teacherto-student interaction during pair work and group work may sometimes take place in languages other than English to aid mutual comprehension and idea generation. However, students should be asked to present their discussion outcomes in English and lecturers should ensure that at least 70\% of class communication takes place in English".

This conceptualisation has been influenced by the works of other scholars who previously proposed that interaction in the EMI classroom was 'probably the most significant pedagogical resource that contributes to learning' [7]. For instance, stemming from the interaction theories within the Second Language Acquisition (SLA) research, Macaro's model refers to comprehensible input, incidental learning, negotiation of meaning, pushed output, and feedback as key ingredients of an interactive EMI process. Perhaps acknowledging that the use of these strategies may not necessarily indicate the presence of learner-centred pedagogy in an EMI classroom, and based on socio-cultural and constructivist theories of learning, Macaro further developed the notion of 'quality interaction in pedagogy' [7]. Although he did not use the term 'learner-centred', one can observe that the purpose of 'quality interaction' is not only to raise lecturers' awareness of students' diverse abilities and needs in an EMI classroom, but also to help lecturers design and deliver less monologic and more dialogic and interactive content courses in English.

Macaro's measures of quality interaction, as shown in Figure 1, reflect the key role of a constructivist pedagogy in EMI effectiveness by promoting 'the student as an active participant in learning an academic subject, moving from preconceptions and misconceptions of how certain (for example, scientific) phenomena occur to a modification of those conceptualisations as a result of new experience, such as an interaction in the classroom' [7]. Recently, this model has been tested in part in a study involving seven universities in Turkey, revealing significant differences in terms of the proportion of first language (L1) use and teacher-student interaction by university type, with less L1 use and interaction found in EMI classes at elite universities [30]. The study identified four variations of EMI pedagogical implementation with respect to language use and interaction: (1) English dominant and teacher-centred; (2) English-dominant interactive; (3) L1-dominant interactive; and (4) L1-dominant and teacher-centred. While such contributions to the research of learner-centred EMI pedagogy are significant, there is still room for broader empirical validation of such practices and the existing interrelationships within different student populations, disciplines, and institutions. Therefore, this study attempts to provide in-depth qualitative insights into the topic by thematically synthesizing student opinion and perceived challenges from a large body of primary qualitative research. 


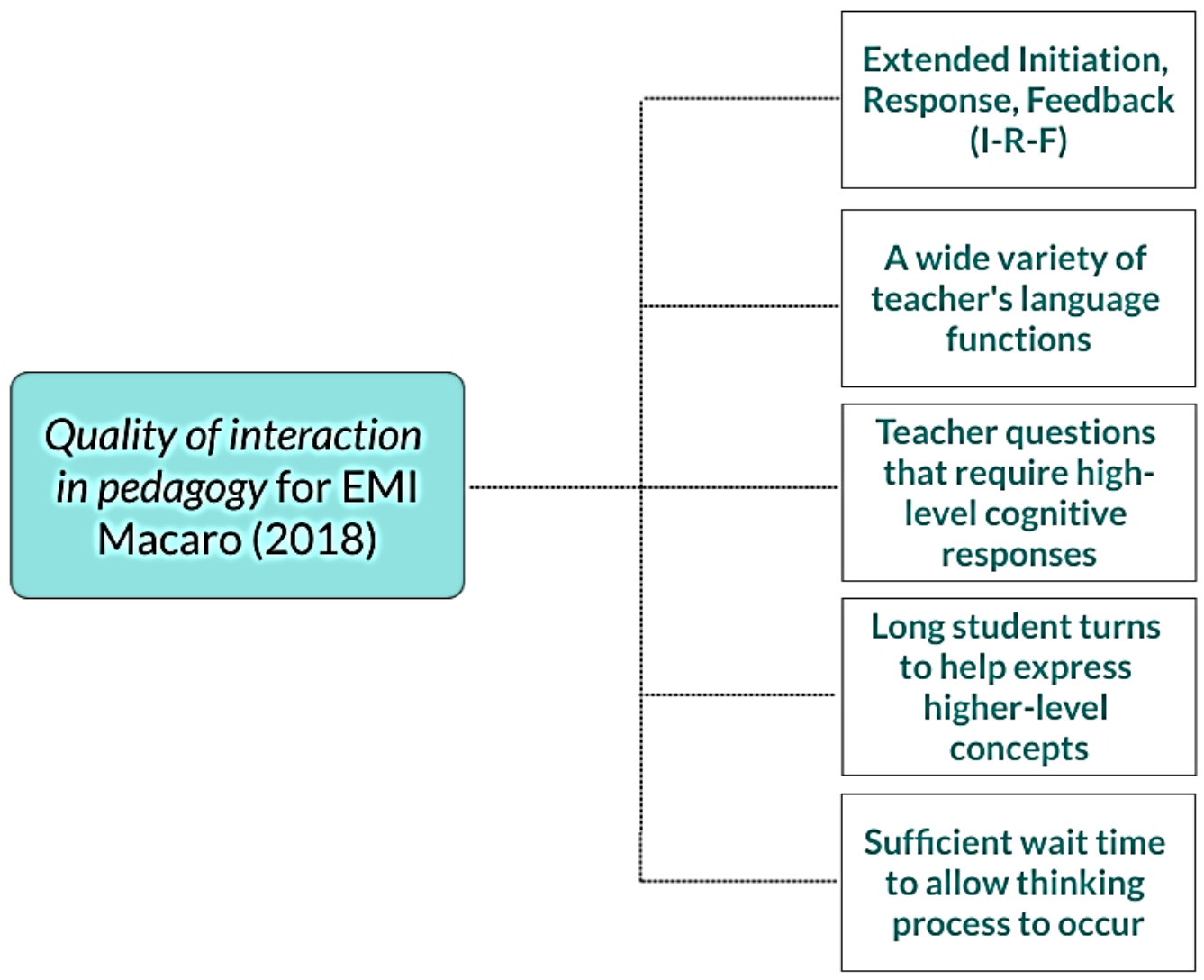

Figure 1. Quality of interaction in EMI pedagogy (adapted from Macaro, 2018 [7]).

Consequently, the main research question that this study addresses is: What are the challenges faced by students enrolled in internationalising universities in different countries and what are the students' views about the obstacles to implementing learner-centred pedagogy in English-medium academic courses?

\section{Materials and Methods}

This systematic thematic synthesis study aimed to identify the challenges in using learner-centred pedagogy in EMI tertiary programmes from a student perspectives. We used an Enhancing Transparency in Reporting the Synthesis of Qualitative Research (ENTREQ) approach to identify the essential articles for analysis and to report the results [58]. This approach suggested three main processes for article identification: literature search and selection (see Figure 2), quality appraisal, and data synthesis.

\subsection{Literature Search and Selection}

Comprehensive searches were carried out in the Web of Science's Core Collection, which included Social Sciences Citation Index (SSCI), Arts and Humanities Citation Index (AHCI), Emerging Sources Citation Index (ESCI), Conference Proceedings Citation Index (CPCI), Book Citation Index (BCI), as well as in the Scopus, ERIC, and Google Scholar databases. Given the systematic scope of the study, we conducted additional searches in the ProQuest Dissertations and Theses database, which indexes abstracts and provides full-text access to dissertations and theses. We also searched the reference lists of relevant publications using forward and backward snowballing methods [59]. The search did not set restrictions on the language of publication. Quantitative studies and systematic reviews were excluded.

Author 1 (M.I.) used Boolean rules to build search strings consisting of multiple combinations of search terms. These search terms were further refined and discussed among the team of researchers (M.I., T.K.F.C., Y.Y., N.D.) and grouped into four broad 
categories, as shown in Table 2. We used 32 search string combinations in total. Examples of some of the search strings used are given below.

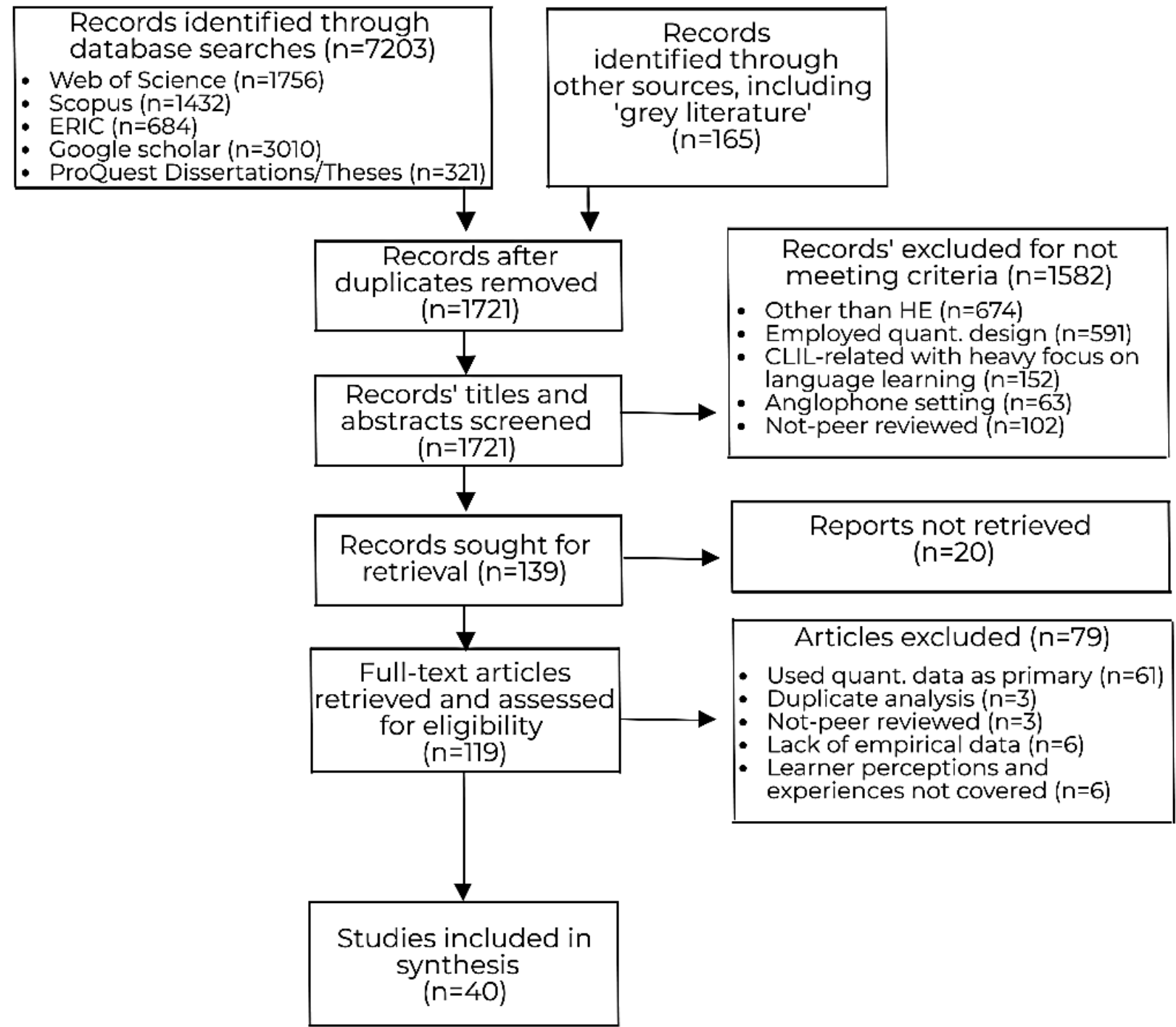

Figure 2. The flow diagram of selection and screening processes.

Table 3 shows the criteria which were used to guide the literature search and selection. Three authors (M.I., Y.Y., N.D.) independently screened the titles and abstracts, removed those that did not meet the inclusion criteria, and assessed full-text versions of the selected studies for eligibility.

- $\quad$ TOPIC: (English medium instruction) AND TOPIC: (teaching) AND TOPIC: (students) AND TOPIC: (perceptions) AND TOPIC: (university).

- $\quad$ TOPIC: (EMI) AND TOPIC: (pedagogy) AND TOPIC: (students) AND TOPIC: (views) AND TOPIC: (higher education). 
Table 2. Terms and concepts used as search strings.

\begin{tabular}{|c|c|}
\hline Category & Possible Alternatives to be Used in Search Strings \\
\hline Learning environment & $\begin{array}{l}\text { (English medium instruction | EMI | English-medium instruction | } \\
\text { English medium of instruction | English as the medium of instruction } \\
\text { | English as a medium of instruction | English language as medium of } \\
\text { instruction | English-medium education | English-medium higher } \\
\text { education | English-medium teaching | English-medium university | } \\
\text { English-medium courses | English-medium programmes | } \\
\text { English-medium programs | English as the lingua franca medium of } \\
\text { instruction | English medium content classes) } \\
\text { (CLIL | Content and Language Integrated Learning | } \\
\text { Content-Language Integrated Learning | Content-Based Instruction | } \\
\text { Content-Based Language Teaching | Immersion Education | English } \\
\text { for Specific Purposes | English for Academic Purposes) }\end{array}$ \\
\hline $\begin{array}{l}\text { Pedagogical } \\
\text { approaches }\end{array}$ & $\begin{array}{c}\text { (pedagogy | pedagogical | pedagogic | teaching | classroom-based | } \\
\text { interactive | didactic | learner-centred | student-centered | } \\
\text { student-centred | teacher-centered | teacher-centred) }\end{array}$ \\
\hline Participants & $\begin{array}{c}\text { (students | learners | needs | perceptions | views | challenges | } \\
\text { experiences | obstacles | difficulties) }\end{array}$ \\
\hline Educational level & (higher education I university | college I tertiary education) \\
\hline
\end{tabular}

Table 3. Filtering criteria for search, selection, and quality appraisal.

\begin{tabular}{|c|c|c|}
\hline Type & Category & Definition \\
\hline $\begin{array}{l}\text { Search and } \\
\text { selection }\end{array}$ & Participants & $\begin{array}{l}\text { Literature addressing student needs when studying academic subjects using } \\
\text { English; learners' perspectives on challenges and obstacles (as opposed to faculty } \\
\text { or administrator views). }\end{array}$ \\
\hline $\begin{array}{l}\text { Search and } \\
\text { selection }\end{array}$ & $\begin{array}{l}\text { Learning } \\
\text { environment }\end{array}$ & $\begin{array}{l}\text { Literature entitled or described as Content and Language Integrated Learning } \\
\text { (CLIL) or Immersion, but nonetheless following the 'Country' criterion below. }\end{array}$ \\
\hline $\begin{array}{l}\text { Search and } \\
\text { selection }\end{array}$ & Publication date & Published or made accessible from database inception to February 2021. \\
\hline Selection & Country & $\begin{array}{l}\text { Literature presenting studies of which the whole research or significant parts were } \\
\text { conducted in countries or jurisdictions in which the first language of the } \\
\text { population was not English. (For example, the synthesis included studies from South } \\
\text { Africa, which may fairly be considered an English-speaking country. However, according } \\
\text { to official information (https://www.gov.za/, accessed on } 21 \text { April 2021), the country has } \\
11 \text { official languages, with over one quarter (25.3\%) of population speaking isiZulu). }\end{array}$ \\
\hline Selection & Education phase & $\begin{array}{l}\text { Literature findings focus on students in higher education: undergraduate, } \\
\text { graduate, and doctoral levels, excluding professional faculty and continuing } \\
\text { education. }\end{array}$ \\
\hline Selection & Document type & $\begin{array}{l}\text { Published (e.g., journal articles, books, and book chapters which did not duplicate } \\
\text { journal articles) and 'grey literature', that is, unpublished or published in } \\
\text { non-commercial forms (e.g., conference proceedings, dissertations, and reports). }\end{array}$ \\
\hline Selection & Language & No restrictions \\
\hline
\end{tabular}

\subsection{Quality Appraisal}

The comprehensiveness of the reporting in each primary qualitative study was assessed in two stages. Initially, independent reviewers (M.I., Y.Y., N.D.) used the CASP Qualitative Studies Checklist [60], a set of ten items designed to be answered with 'yes' /'can't tell' /'no' when critically assessing the comprehensiveness of each article. The studies that received at least 8 out of 10 'yes' answers by two independent reviewers as well as the ones that used interviews and focus groups to examine student experiences were then subjected to an additional check using the Consolidated Criteria for Reporting Qualitative research (COREQ) [61]. This framework allows reviewers to identify explicit and comprehensive reporting of studies that used in-depth interviews and focus groups to collect data and evaluate the transferability of the findings to their own settings. The COREQ's 32 items are grouped into three domains: (i) research team and reflexivity; (ii) study design; and (iii) data analysis and reporting. Three authors (M.I., Y.Y. and N.D.) assessed each eligible study independently using the COREQ framework and resolved any disagreements through discussion. The authors followed a four-stage approach (identification, screening, 
eligibility, and inclusion [62]) to select articles for further analysis; this process is illustrated in Figure 2.

\subsection{Data Synthesis}

This study used Thomas and Harden's systematic thematic synthesis approach to analyse 40 selected articles [63]. This approach integrates the findings of multiple qualitative studies; the following five steps were used in the analysis:

1. All included papers were read thoroughly by three authors.

2. The first author then extracted and summarised the documents regarding their definition and context of EMI, country of research, sample size, characteristics of academic subjects, study design, methods of analysis, and key research questions (see Table 4).

3. The full-text articles and their descriptors were then assessed independently by three researchers (M.I., Y.Y., N.D.) using the CASP Qualitative Studies Checklist [60] and the Consolidated Criteria for Reporting Qualitative research (COREQ) [61], as mentioned earlier.

4. Data from the results sections of the articles were independently and inductively coded by two authors (M.I., Y.Y, N.D.) line-by-line using MAXQDA Ver. 2020TM, a software programme designed for computer-assisted qualitative and mixed-method data, text, and multimedia analysis (see Figure 3).

5. The results of open coding were organised into descriptive themes. Researchers (M.I. and T.K.F.C.) then compared the developed themes inductively and established the primary analytical domains [63].

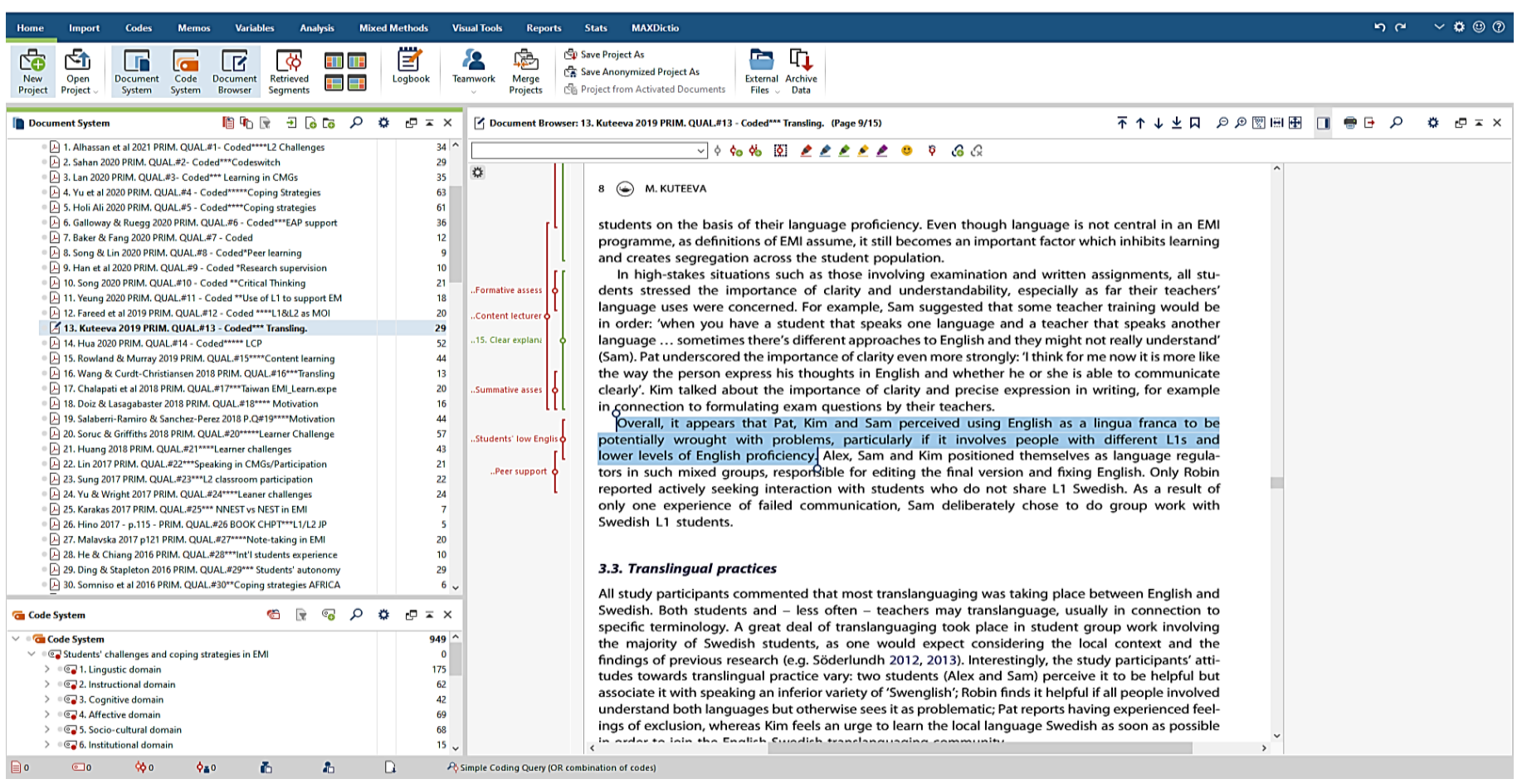

Figure 3. Line-by-line coding in MAXQDA Pro. 2020. 
Table 4. A stratified schema of participant quotations and references reporting each domain and theme.

\begin{tabular}{|c|c|c|c|c|}
\hline $\begin{array}{c}\text { Domain and } \\
\text { Themes Names }\end{array}$ & $\begin{array}{c}\text { Sample Quotations/Authors' Comments } \\
\text { from Selected Primary Qualitative } \\
\text { Studies [Ref.] }\end{array}$ & $\begin{array}{l}N(\%) \text { of Total } \\
\text { Articles (within } \\
\text { Theme) }\end{array}$ & $\begin{array}{l}\text { Articles Reporting } \\
\text { the Themes [Ref.] }\end{array}$ & $\begin{array}{l}N(\%) \text { of Total } \\
\text { Articles (within } \\
\text { Domain) }\end{array}$ \\
\hline \multicolumn{5}{|c|}{ META/LINGUISTIC DOMAIN } \\
\hline $\begin{array}{l}\text { Impracticality of } \\
\text { EMI for some } \\
\text { content disciplines }\end{array}$ & $\begin{array}{l}\text { "For those of us who study Law, English is } \\
\text { not meaningful, and we would rather prefer } \\
\text { other languages like Italian that provides a } \\
\text { context closer to Spanish law" [64]. }\end{array}$ & $11(28)$ & {$[12,53,64-72]$} & \\
\hline $\begin{array}{l}\text { Divergent } \\
\text { perceptions of } \\
\text { English }\end{array}$ & $\begin{array}{c}\text { "I told one of my [local] lab mates, 'You are } \\
\text { good in English, you have many vocabularies. } \\
\text { So why you don't speak with me?' He said he } \\
\text { is not confident from himself. And, this is why } \\
\text { he feels shy to speak in front of me. And, I told } \\
\text { to him, 'Also I am Arabic. My native } \\
\text { language is Arabic, not English, but I can } \\
\text { speak English.' So, he said 'No, you are... } \\
\text { something different" [73]. }\end{array}$ & $5(13)$ & {$[70,73-76]$} & 35 articles $(88 \%)$ \\
\hline $\begin{array}{l}\text { Students' low } \\
\text { (general) English } \\
\text { proficiency }\end{array}$ & $\begin{array}{c}\text { "The major problem I am having now is about } \\
\text { my language proficiency ... so I found it } \\
\text { difficult to study all the common courses in } \\
\text { English by the time I began to study in } \\
\text { university. I couldn't even understand what } \\
\text { my professor was talking about in the tutorial } \\
\text { sessions" [6]. }\end{array}$ & $12(30)$ & $\begin{array}{c}{[6,12,64,66,74,76-} \\
82]\end{array}$ & \\
\hline $\begin{array}{c}\text { Lecturers' low } \\
\text { English proficiency }\end{array}$ & $\begin{array}{c}\text { "I sometimes even thought it would be better } \\
\text { if she had just let the class be open to whole } \\
\text { group discussions rather than giving lectures } \\
\text { herself. I know she is a professional in the field } \\
\text { but because of her language barrier, it is } \\
\text { almost impossible to understand her } \\
\text { lecture" [83]. }\end{array}$ & $10(25)$ & $\begin{array}{c}{[12,53,72,75,79,81} \\
83-86]\end{array}$ & \\
\hline $\begin{array}{c}\text { Lecturers' } \\
\text { non-standard } \\
\text { language functions }\end{array}$ & $\begin{array}{l}\text { "[The problem is] pronunciation of some } \\
\text { specific words because the way they are } \\
\text { pronounced by the lecturer differs from how I } \\
\text { am used to pronouncing them" [75]. }\end{array}$ & $7(18)$ & {$[53,67,75,81,86-88]$} & \\
\hline $\begin{array}{l}\text { Native vs. } \\
\text { non-native } \\
\text { English-speaking } \\
\text { lecturer preferences }\end{array}$ & $\begin{array}{l}\text { "I'd definitely go for a NEST [native } \\
\text { English-speaking teacher]. It is because they } \\
\text { have nothing to do with language issues while } \\
\text { NNESTs experience troubles in delivering } \\
\text { courses." [80]."I think if it is an engineering } \\
\text { course I would probably prefer a Turkish } \\
\text { lecturer/... /because the other one is a } \\
\text { "native speaker" he often speaks too fast } \\
\text { without realizing it/... /especially he } \\
\text { frequently uses unfamiliar terms" [80]. }\end{array}$ & $4(10)$ & {$[53,71,80,88]$} & \\
\hline $\begin{array}{l}\text { Lecturers' poor } \\
\text { language } \\
\text { awareness and } \\
\text { support }\end{array}$ & $\begin{array}{l}\text { "Because the professor is from Hong Kong, } \\
\text { many students just spoke Cantonese to } \\
\text { respond to questions. But the professor } \\
\text { required us to speak in English. The students } \\
\text { didn't seem to like it and stuttered so much } \\
\text { when they spoke" [74]. }\end{array}$ & $9(23)$ & $\begin{array}{c}{[53,68,69,74,78,83} \\
88-90]\end{array}$ & \\
\hline
\end{tabular}


Table 4. Cont.

\begin{tabular}{|c|c|c|c|c|}
\hline $\begin{array}{l}\text { Domain and } \\
\text { Themes Names }\end{array}$ & $\begin{array}{c}\text { Sample Quotations/Authors' Comments } \\
\text { from Selected Primary Qualitative } \\
\text { Studies [Ref.] }\end{array}$ & $\begin{array}{l}N(\%) \text { of Total } \\
\text { Articles (within } \\
\text { Theme) }\end{array}$ & $\begin{array}{l}\text { Articles Reporting } \\
\text { the Themes [Ref.] }\end{array}$ & $\begin{array}{l}N(\%) \text { of Total } \\
\text { Articles (within } \\
\text { Domain) }\end{array}$ \\
\hline \multicolumn{5}{|c|}{ META/LINGUISTIC DOMAIN } \\
\hline $\begin{array}{l}\text { Extensive } \\
\text { code-switching and } \\
\text { translanguaging }\end{array}$ & $\begin{array}{l}\text { "Sometimes like even during the lectures } \\
\text { when you're like commenting on- on } \\
\text { something, I usually do that in Swedish. It's } \\
\text { not necessarily English. It's like switching } \\
\text { back and forth. It really depends, so [ . . ]" } \\
\text { [78]. "If we needed to say something and the } \\
\text { subject was a bit more difficult, we spoke in } \\
\text { Italian" [53] (code-switching). "They get } \\
\text { caught up with their own language. That } \\
\text { happened to me in my Civil Engineering } \\
\text { practical work. We were a group of nine people } \\
\text { and I was the only non-local and everyone just } \\
\text { spoke Cantonese" [6] (translanguaging). }\end{array}$ & $12(30)$ & $\begin{array}{c}{[6,12,53,64,66,67,74-} \\
76,78,89,91]\end{array}$ & \\
\hline $\begin{array}{l}\text { Extensive use of } L 1 \\
\quad \text { in classroom }\end{array}$ & $\begin{array}{c}\text { "Yes, our mother tongue was a great help for } \\
\text { us in translation and interpreting technical } \\
\text { terms and concepts. I use dictionaries to help } \\
\text { me translate technical words into Arabic ... } \\
\text { The teacher was an Arabic speaker and I used } \\
\text { to understand and comprehend } 97 \% \text { of the } \\
\text { lectures" [65]. }\end{array}$ & $6(15)$ & {$[13,65-67,78,90]$} & \\
\hline $\begin{array}{l}\text { Speaking and oral } \\
\text { presentation skills }\end{array}$ & $\begin{array}{l}\text { "It may already be difficult to talk about a } \\
\text { graph in Spanish, so what do I say now in } \\
\text { English? Yes, I'm twice as nervous" [68]. }\end{array}$ & $14(35)$ & $\begin{array}{c}{[6,12,52,53,64,66,68} \\
73,74,81,82,89,91 \\
92]\end{array}$ & \\
\hline $\begin{array}{l}\text { Inadequate English } \\
\text { vocabulary }\end{array}$ & $\begin{array}{l}\text { "I used dictionaries to look up every word in } \\
\text { the lesson when I did not understand what the } \\
\text { professor was saying" [13]. }\end{array}$ & $10(25)$ & $\begin{array}{c}{[12,13,65,67,68,81,} \\
90,91,93,94]\end{array}$ & \\
\hline $\begin{array}{l}\text { Academic writing } \\
\text { skills }\end{array}$ & $\begin{array}{l}\text { "I think people have got problems with } \\
\text { writing. People can't write. They know for } \\
\text { instance, the word and they pronounce it but } \\
\text { they can't write it. This is a real problem. You } \\
\text { find someone talks about the topic and } \\
\text { understands the topic and when it comes to } \\
\text { writing they make mistakes. You feel there are } \\
\text { problems with structure, grammar, and } \\
\text { clarity" [91]. }\end{array}$ & $9(23)$ & $\begin{array}{c}{[6,53,65,72,81-} \\
83,90,91]\end{array}$ & \\
\hline $\begin{array}{c}\text { Lecture } \\
\text { comprehension }\end{array}$ & $\begin{array}{c}\text { "If the lecture is held in our first language, } \\
\text { even when we are doing our own things, we } \\
\text { can still get the content... However, it is } \\
\text { totally different when the language changes to } \\
\text { English... Thus, if I do not focus on the } \\
\text { lecture, then the lecture becomes a background } \\
\text { sound, like birding humming in the } \\
\text { background. I wouldn't care what the content } \\
\text { is" [52]. }\end{array}$ & $11(28)$ & $\begin{array}{c}{[12,52,53,66,75,81,} \\
82,86,88,90,91]\end{array}$ & \\
\hline $\begin{array}{l}\text { Bilingual } \\
\text { instructional } \\
\text { materials }\end{array}$ & $\begin{array}{l}\text { "We sometimes translate the whole handout } \\
\text { [into Arabic] to understand it in a better way" } \\
\text { [65]."Wordy and complex texts" [67]. }\end{array}$ & $6(15)$ & {$[12,13,53,65,67,79]$} & \\
\hline
\end{tabular}


Table 4. Cont.

\begin{tabular}{|c|c|c|c|c|}
\hline $\begin{array}{c}\text { Domain and } \\
\text { Themes Names }\end{array}$ & $\begin{array}{c}\text { Sample Quotations/Authors' Comments } \\
\text { from Selected Primary Qualitative } \\
\text { Studies [Ref.] }\end{array}$ & $\begin{array}{l}N(\%) \text { of Total } \\
\text { Articles (within } \\
\text { Theme) }\end{array}$ & $\begin{array}{l}\text { Articles Reporting } \\
\text { the Themes [Ref.] }\end{array}$ & $\begin{array}{l}N(\%) \text { of Total } \\
\text { Articles (within } \\
\text { Domain) }\end{array}$ \\
\hline \multicolumn{5}{|c|}{ INSTRUCTIONAL DOMAIN } \\
\hline $\begin{array}{l}\text { Monologic, } \\
\text { non-interactive } \\
\text { lecturing }\end{array}$ & $\begin{array}{c}\text { "I think the lecturer's teaching approach is } \\
\text { very rigid, and inflexible, with the same } \\
\text { pattern all the time. She just literally reads } \\
\text { from the textbook and covers the material in } \\
\text { the textbook. Nothing special for her teaching } \\
\text { approach. This results in the class atmosphere } \\
\text { being completely dead [literal translation } \\
\text { "Dead Air"]" [52]. }\end{array}$ & $10(25)$ & $\begin{array}{c}{[6,12,52,53,64,67,79,} \\
84,86,87]\end{array}$ & \\
\hline Assessment issues & $\begin{array}{l}\text { "[Course Title] has multiple choice questions } \\
\text {... So if you can do exercises, it'll be okay. } \\
\text { And for [Course Title], you need to do every } \\
\text { exercise. The test questions are similar (to } \\
\text { those in the textbook)... Just memorise the } \\
\text { test questions, and input, output. I forgot } \\
\text { after the exam" [84]. }\end{array}$ & $10(25)$ & $\begin{array}{c}{[6,53,64-} \\
67,72,78,84,88]\end{array}$ & \\
\hline $\begin{array}{l}\text { Attending to } \\
\text { students' diverse } \\
\text { needs/abilities }\end{array}$ & $\begin{array}{l}\text { "So ... in the first class we took SAT test, and } \\
\text { it was not difficult for us [ local students]. } \\
\text { Just a few words we don't understand ... I } \\
\text { think it's for talented junior high students } \\
\text {... . So what the instructor taught is not } \\
\text { difficult for us, but rather difficult for } \\
\text { international students. The instructor needs } \\
\text { to make a balance" [84]. }\end{array}$ & $6(15)$ & {$[6,12,52,79,82,84]$} & 21 articles $(53 \%)$ \\
\hline $\begin{array}{l}\text { Non-attending to } \\
\text { students' personal } \\
\text { qualities and } \\
\text { cultural } \\
\text { sensitivities }\end{array}$ & $\begin{array}{l}\text { "The professor, like: 'Come on, say something.' } \\
\text { 'You have, you have something to say, right?' } \\
\text { And you're like, really? Nothing (laughs). [ } \\
\text {.. I I think they are more soft with the local } \\
\text { because the local don't speak, they think that } \\
\text { the international would do it, so they put you } \\
\text { in the corner" [73]. }\end{array}$ & $4(10)$ & {$[6,73,82,83]$} & \\
\hline $\begin{array}{l}\text { Lecturers' speaking } \\
\text { rate }\end{array}$ & $\begin{array}{l}\text { "There was a problem in the accounting } \\
\text { courses. For instance, we couldn't understand } \\
\text { from the teacher of Financial Accounting } \\
\text { course in semester one. Even those who } \\
\text { graduated from the school here and who have } \\
\text { business backgrounds faced a problem with } \\
\text { understanding the teacher... she was } \\
\text { fast" [91]. }\end{array}$ & $5(13)$ & {$[12,52,75,90,91]$} & \\
\hline $\begin{array}{l}\text { Lack of } \\
\text { clarification and } \\
\text { corrective feedback } \\
\text { from lecturers }\end{array}$ & $\begin{array}{l}\text { "I think EMI leaves too much pressure on } \\
\text { Korean students, and I feel like I have to } \\
\text { survive on my own. I am sure my } \\
\text { assignments submitted in English are full of } \\
\text { grammar errors, but I don't get any feedback } \\
\text { on my writing from the instructor. I } \\
\text { sometimes feel frustrated that there is little } \\
\text { support for Korean students whose mother } \\
\text { tongue is Korean and who is not familiar at all } \\
\text { with learning in English" [83]. }\end{array}$ & $5(13)$ & {$[13,65,75,83,90]$} & \\
\hline
\end{tabular}


Table 4. Cont.

\begin{tabular}{|c|c|c|c|c|}
\hline $\begin{array}{l}\text { Domain and } \\
\text { Themes Names }\end{array}$ & $\begin{array}{c}\text { Sample Quotations/Authors' Comments } \\
\text { from Selected Primary Qualitative } \\
\text { Studies [Ref.] }\end{array}$ & $\begin{array}{l}N(\%) \text { of Total } \\
\text { Articles (within } \\
\text { Theme) }\end{array}$ & $\begin{array}{l}\text { Articles Reporting } \\
\text { the Themes [Ref.] }\end{array}$ & $\begin{array}{l}N(\%) \text { of Total } \\
\text { Articles (within } \\
\text { Domain) }\end{array}$ \\
\hline \multicolumn{5}{|c|}{$\begin{array}{r}\text { SOCIO-CULTURAL DOMAIN } \\
\text { Theme }\end{array}$} \\
\hline $\begin{array}{c}\text { Communication } \\
\text { among } \\
\text { homelinternational } \\
\text { students }\end{array}$ & $\begin{array}{l}\text { "... we have a [Mainland] Chinese girl in } \\
\text { our class, and she has a bit of problems with } \\
\text { English, so she doesn't understand what I'm } \\
\text { telling her so when we, we were in the same } \\
\text { group and she didn't understand what I } \\
\text { wanted from her so we had a } \\
\text { misunderstanding in the group work which } \\
\text { resulted in a worse grade" [78]. }\end{array}$ & $9(23)$ & $\begin{array}{c}{[6,12,77-79,81-} \\
83,85]\end{array}$ & \\
\hline In-group pressures & $\begin{array}{l}\text { "Similarly, following just one incident of } \\
\text { working in a mixed group which included two } \\
\text { students from [Mainland] China, Sam had } \\
\text { avoided working in such groups in the EMI } \\
\text { programme: 'since then I have sort of tried to } \\
\text { find at least people who speak Swedish or } \\
\text { English" [78]. }\end{array}$ & $6(15)$ & {$[73,74,77,78,84,95]$} & \\
\hline $\begin{array}{c}\text { Multiple and/or } \\
\text { unfamiliar accents }\end{array}$ & $\begin{array}{l}\text { "At first, I did have great difficulties in } \\
\text { understanding international students from } \\
\text { Pakistan or India. They had a very good grasp } \\
\text { of knowledge and spoke quite fluently, but I } \\
\text { did not understand what they said due to their } \\
\text { accents" [95]. }\end{array}$ & $6(15)$ & {$[6,12,71,77,85,95]$} & 21 articles $53 \%$ \\
\hline Peer support & $\begin{array}{l}\text { "Even in peer learning groups they preferred } \\
\text { to work together as Rwandans. One reason for } \\
\text { this ... was that South African students } \\
\text { looked down on them because they were not } \\
\text { proficient in English" [82]. }\end{array}$ & $4(10)$ & {$[78,82,88,95]$} & \\
\hline $\begin{array}{l}\text { Divergent attitudes } \\
\text { toward class } \\
\text { participation }\end{array}$ & $\begin{array}{c}\text { "I mean my basic think is there is a question, } \\
\text { the teacher is asking, and I'm, like, thinking, } \\
\text { 'Do I have anything to say, regardless of who } \\
\text { is there and what they do and think?' [ . . I } \\
\text { And if I feel like I have something to say, I say } \\
\text { it." [73]. }\end{array}$ & $5(13)$ & {$[73,74,84-86]$} & \\
\hline $\begin{array}{l}\text { Collaborative } \\
\text { learning and } \\
\text { teamwork }\end{array}$ & $\begin{array}{l}\text { "If a student in my secondary school refused } \\
\text { to do anything when s/he was doing a project, } \\
\text { they would be caught and punished. But in } \\
\text { university, professors won't care about which } \\
\text { student is a free rider. They only care about } \\
\text { how good their students' group project is and } \\
\text { give marks based on the quality of the } \\
\text { project" [6]. }\end{array}$ & $5(13)$ & {$[6,78,96-98]$} & \\
\hline
\end{tabular}


Table 4. Cont.

\begin{tabular}{|c|c|c|c|c|}
\hline $\begin{array}{c}\text { Domain and } \\
\text { Themes Names }\end{array}$ & $\begin{array}{c}\text { Sample Quotations/Authors' Comments } \\
\text { from Selected Primary Qualitative } \\
\text { Studies [Ref.] }\end{array}$ & $\begin{array}{l}N(\%) \text { of Total } \\
\text { Articles (within } \\
\text { Theme) }\end{array}$ & $\begin{array}{l}\text { Articles Reporting } \\
\text { the Themes [Ref.] }\end{array}$ & $\begin{array}{l}N(\%) \text { of Total } \\
\text { Articles (within } \\
\text { Domain) }\end{array}$ \\
\hline \multicolumn{5}{|c|}{ META/COGNITIVE DOMAIN } \\
\hline $\begin{array}{l}\text { Processing and } \\
\text { comprehension of } \\
\text { difficult content }\end{array}$ & $\begin{array}{l}\text { "[When concepts were complex to explain] } \\
\text { 'even for the lecturers, it sometimes became a } \\
\text { bit tricky" [53]."Like in the textbook a section } \\
\text { requires us to reflect on the theory ... . } \\
\text { Provide examples ... . But the instructor } \\
\text { skipped it ... . But with reading by myself, I } \\
\text { can take time to think" [84]. }\end{array}$ & $11(28)$ & $\begin{array}{c}{[12,52,53,65,67-} \\
69,75,76,79,84]\end{array}$ & \multirow{6}{*}{19 articles $(48 \%)$} \\
\hline $\begin{array}{c}\text { Poor background } \\
\text { knowledge }\end{array}$ & $\begin{array}{c}\text { "... Students with weaker English, coupled } \\
\text { with a weaker background in science, could } \\
\text { sometimes struggle with the extensive reading } \\
\text { required on the MSc" [53]. }\end{array}$ & $4(10)$ & {$[52,53,88,91]$} & \\
\hline $\begin{array}{l}\text { Over- } \\
\text { simplification of } \\
\text { content }\end{array}$ & $\begin{array}{l}\text { "What is taught [via EMI] will be relatively } \\
\text { easy and the test is easier" [84]. "The } \\
\text { emphasis on learners' inadequate English } \\
\text { proficiency compels the instructors to lower } \\
\text { their expectations about student } \\
\text { performance" [88]. }\end{array}$ & $3(8)$ & {$[74,84,88]$} & \\
\hline $\begin{array}{l}\text { Extensive use of } \\
\text { technical language }\end{array}$ & $\begin{array}{l}\text { "It is common that we don't know what is } \\
\text { being taught in the lecture so we need to spend } \\
\text { a lot of time on looking up the meaning of } \\
\text { some technical words so we understand what } \\
\text { will be taught before the lecture begins" [6]. }\end{array}$ & $7(18)$ & {$[6,12,72,75,88,91,94]$} & \\
\hline $\begin{array}{l}\text { Lack of practical } \\
\text { demonstra- } \\
\text { tion/application of } \\
\quad \text { knowledge }\end{array}$ & $\begin{array}{l}\text { "Seriously, for the content of the course, I have } \\
\text { no idea how it influences me... I feel like I } \\
\text { am still a test-taking machine, studying those } \\
\text { theories. I can barely see how it makes my life } \\
\text { better; it's kind of no use to my daily life" [84]. }\end{array}$ & $3(8)$ & {$[67,74,84]$} & \\
\hline $\begin{array}{l}\text { Poor rhetorical and } \\
\text { critical thinking } \\
\text { skills }\end{array}$ & $\begin{array}{l}\text { "When it comes to discussion, it's usually just } \\
\text { silence and until someone breaks it, it's always } \\
\text { really reluctant. From my experience in the } \\
\text { UK, people are a lot more engaged and } \\
\text { argumentative, so that's one thing that really } \\
\text { stands out [6]. "Everyone expected you to } \\
\text { give a critical opinion, but nobody trained you } \\
\text { how to do a critical assessment. The school } \\
\text { system that I went through didn't train you } \\
\text { how to be critical, like outside the box" [97]. }\end{array}$ & $3(8)$ & {$[6,83,97]$} & \\
\hline
\end{tabular}


Table 4. Cont.

\begin{tabular}{|c|c|c|c|c|}
\hline $\begin{array}{c}\text { Domain and } \\
\text { Themes Names }\end{array}$ & $\begin{array}{c}\text { Sample Quotations/Authors' Comments } \\
\text { from Selected Primary Qualitative } \\
\text { Studies [Ref.] }\end{array}$ & $\begin{array}{l}N(\%) \text { of Total } \\
\text { Articles (within } \\
\text { Theme) }\end{array}$ & $\begin{array}{l}\text { Articles Reporting } \\
\text { the Themes [Ref.] }\end{array}$ & $\begin{array}{l}N(\%) \text { of Total } \\
\text { Articles (within } \\
\text { Domain) }\end{array}$ \\
\hline \multicolumn{5}{|c|}{ AFFECTIVE DOMAIN } \\
\hline Lack of confidence & $\begin{array}{c}\text { "I feel shy. Embarrassed. I can't catch up with } \\
\text { the teacher because my English is not good, } \\
\text { and my memory is not so strong to keep all } \\
\text { information" [12]. }\end{array}$ & $6(15)$ & {$[12,13,52,64,79,82]$} & \\
\hline Fear of losing face & $\begin{array}{l}\text { "My English is not so good, so I find myself } \\
\text { suffering a lot when sitting in EMI } \\
\text { classrooms. I did not ask questions in class } \\
\text { because I was afraid that I cannot make myself } \\
\text { understood. When the instructors asked "are } \\
\text { you with me"? I would always say "yes", } \\
\text { even though I was not. If I said "no", I was } \\
\text { afraid that I could not understand the } \\
\text { instructors' further explanations." [13]. }\end{array}$ & $5(13)$ & {$[12,13,64,68,74]$} & 16 articles $(40 \%)$ \\
\hline $\begin{array}{c}\text { Teacher-student } \\
\text { rapport }\end{array}$ & $\begin{array}{l}\text { "Yet this is not the case with teachers who are } \\
\text { native speakers of English. We dared not ask } \\
\text { them for clarification after class because we } \\
\text { cannot understand their English" [13]. }\end{array}$ & $2(5)$ & {$[13,95]$} & \\
\hline Frustration & $\begin{array}{l}\text { "Some students do not understand what the } \\
\text { teacher says and that interrupts the flow of the } \\
\text { class that becomes really slow and some of us } \\
\text { feel frustrated" [64]. }\end{array}$ & $6(15)$ & {$[6,12,64,74,79,95]$} & \\
\hline Dissatisfaction & $\begin{array}{l}\text { "Though those who earn the first place in the } \\
\text { department will attend classes, showing their } \\
\text { passion, but in general ... I see classmates are } \\
\text { using smartphones. I don't want to be like } \\
\text { that [skip classes], but I feel it boring and } \\
\text { cannot listen to anything" [84]. }\end{array}$ & $5(13)$ & {$[68,74,79,84,87]$} & \\
\hline Anxiety and stress & $\begin{array}{l}\text { "I could understand only } 10 \%-20 \% \text { of the } \\
\text { lectures in the first few weeks. The teacher for } \\
\text { our core course speaks English with a strong } \\
\text { Hong Kong accent. I was very nervous. But } \\
\text { the more nervous I was, the harder it was for } \\
\text { me to understand the teacher" [81]. }\end{array}$ & $5(13)$ & {$[6,52,64,68,81]$} & \\
\hline Boredom & $\begin{array}{c}\text { "It's just like senior high school, listening } \\
\text { during the class, one-way delivering, and back } \\
\text { to home study, finally aiming to score high on } \\
\text { the test. I cannot figure out what's the } \\
\text { difference between college and senior high } \\
\text { school. This kind of feeling continues in } \\
\text { [Course Title]" [84]. }\end{array}$ & $3(8)$ & {$[12,52,84]$} & \\
\hline Fatigue & $\begin{array}{c}\text { "What made the situation worse is that the } \\
\text { lecturer would continue the lesson without } \\
\text { any breaks" [52]. }\end{array}$ & $2(5)$ & {$[12,52]$} & \\
\hline $\begin{array}{c}\text { Intrinsic } \\
\text { motivation }\end{array}$ & $\begin{array}{c}\text { "In addition to the academic reasons such as } \\
\text { getting a "certificate" because it is essential } \\
\text { for the future, I also like listening to "music" } \\
\text { "in English," and I watch TV "in English" } \\
\text { more" [68]. }\end{array}$ & $5(13)$ & {$[13,65,66,68,84]$} & \\
\hline $\begin{array}{c}\text { Extrinsic } \\
\text { motivation }\end{array}$ & $\begin{array}{c}\text { "They [parents] are always telling me that } \\
\text { English is extremely important". "They are a } \\
\text { drag, a pest" [68]. }\end{array}$ & $4(10)$ & {$[12,53,68,84]$} & \\
\hline
\end{tabular}


Table 4. Cont.

\begin{tabular}{|c|c|c|c|c|}
\hline $\begin{array}{l}\text { Domain and } \\
\text { Themes Names }\end{array}$ & $\begin{array}{c}\text { Sample Quotations/Authors' Comments } \\
\text { from Selected Primary Qualitative } \\
\text { Studies [Ref.] }\end{array}$ & $\begin{array}{l}N(\%) \text { of Total } \\
\text { Articles (within } \\
\text { Theme) }\end{array}$ & $\begin{array}{l}\text { Articles Reporting } \\
\text { the Themes [Ref.] }\end{array}$ & $\begin{array}{l}N(\%) \text { of Total } \\
\text { Articles (within } \\
\text { Domain) }\end{array}$ \\
\hline \multicolumn{5}{|c|}{$\begin{array}{l}\text { INSTITUTIONAL DOMAIN } \\
\qquad \text { Themes related to university-wide EMI policies and conditions affecting students' learning }\end{array}$} \\
\hline $\begin{array}{l}\text { Ineffective } \\
\text { curriculum } \\
\text { designs and } \\
\text { planning }\end{array}$ & $\begin{array}{l}\text { "It [EMI course] was generally not effective; } \\
\text { for some it was too short, for others the } \\
\text { methodology was not suited to beginners and } \\
\text { others considered the level of the course too } \\
\text { low or 'irrelevant' to postgraduate students" } \\
\text { [82]. }\end{array}$ & $4(10)$ & {$[74,79,82,87]$} & \\
\hline $\begin{array}{c}\text { Inadequate } \\
\text { self-access support }\end{array}$ & $\begin{array}{l}\text { Both staff and students criticised support with } \\
\text { regard to its availability, effectiveness, or, in } \\
\text { one case, price. "While "special TOEFL } \\
\text { classes" are sometimes offered, Sandra } \\
\text { (Domestic student, University C) doesn't "go } \\
\text { to these classes as they are expensive. They are } \\
\text { not free. 30,000 Yen" [89]. }\end{array}$ & $4(10)$ & {$[53,82,89,93]$} & 8 articles $(20 \%)$ \\
\hline $\begin{array}{l}\text { EAP courses not } \\
\text { meeting students' } \\
\text { needs }\end{array}$ & $\begin{array}{l}\text { "I took one such course offered by the } \\
\text { university in order to improve my spoken } \\
\text { English and grammar use. However, I found } \\
\text { the instructor simply taught the course in } \\
\text { English, pretty much like the way other } \\
\text { marketing major-related classes were taught, } \\
\text { rather than really targeting my spoken and } \\
\text { grammar problems" [13]. }\end{array}$ & $3(8)$ & {$[13,82,89]$} & \\
\hline
\end{tabular}

The final process resulted in the inclusion of 40 studies that qualified for the synthesis. Detailed descriptors of the studies included in the synthesis are given in Appendix A.

\section{Results}

The selected 40 studies included 1769 participants from 20 countries and jurisdictions (see Figure 4). The six main analytical domains related to the issues and obstacles faced by students during their content learning with EMI were identified. These were the meta/linguistic (reported by 35 studies), instructional (21 studies), socio-cultural (21 studies), meta/cognitive (19 studies), affective (16 studies), and institutional domains (8 studies), as illustrated in Figure 5. Selected quotations illustrating each descriptive theme are provided in Table 4 .

\subsection{Meta/Linguistic Domain}

First, we explored the themes related to the students' attitudes toward content learning through EMI. Students referred to the impracticality of EMI for some content disciplines in 11 studies. Some students expressed concerns and negative feelings [64,65,68,70], while in other studies they voiced mixed or positive views regarding the practical utility of EMI for studying content $[12,53,67,69,71,72]$. In addition, students seemed to have divergent perceptions of English in content classrooms, especially when it comes to comparisons among international and home students [70,73-76]. Some international students believed they were 'as much non-native English speakers' as home students, however, they regarded English as 'just a medium for communication' and 'felt no need to be concerned about making mistakes' [73,74], whereas home students expected native-like English from teachers and peers alike [73]. Other students perceived English as 'an imposed lingua franca' that limited the possibility of 'having courses delivered in both the local and other foreign languages' [70]. 


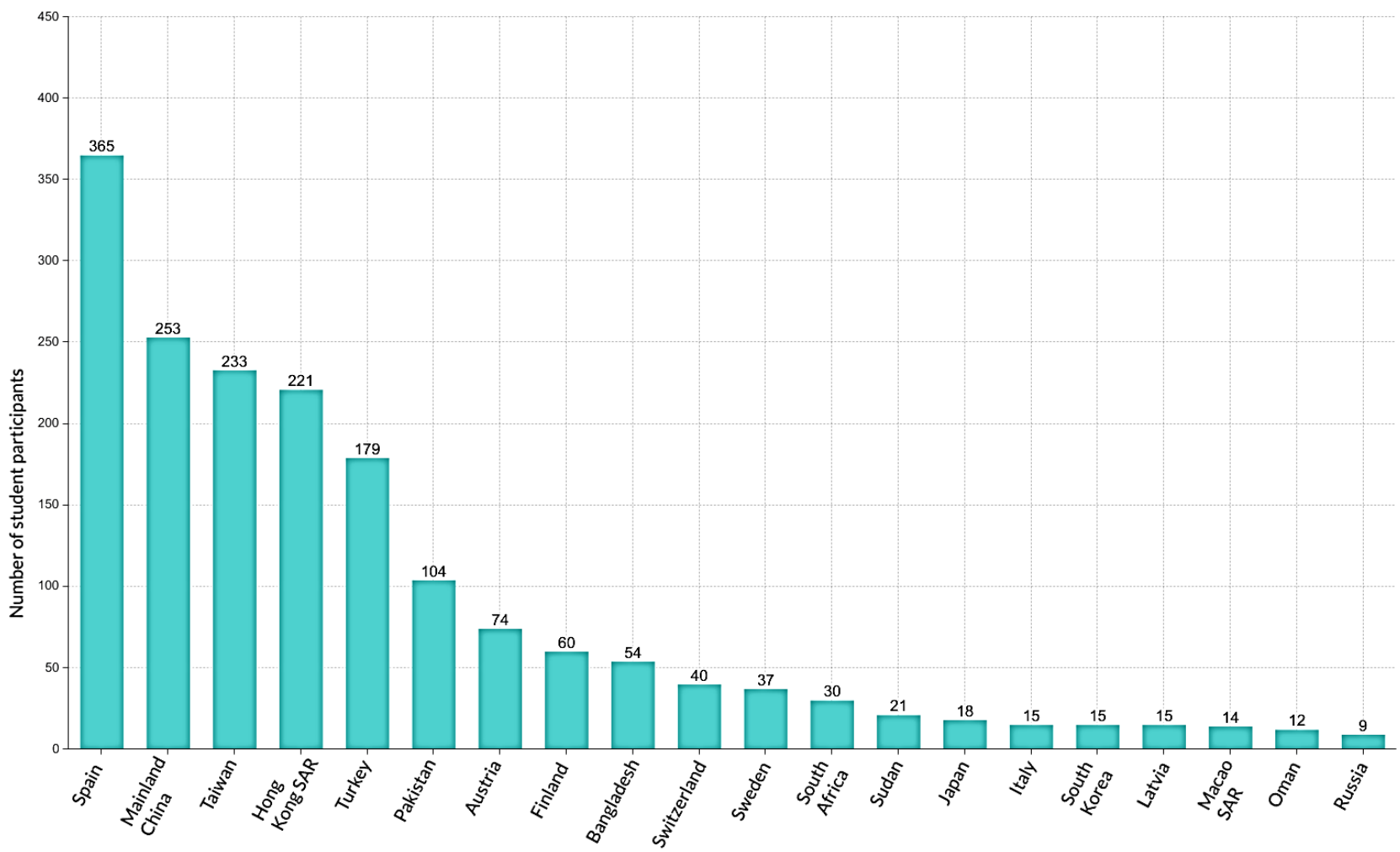

Figure 4. Representation of student participants by country or jurisdiction $(N=1769)$.

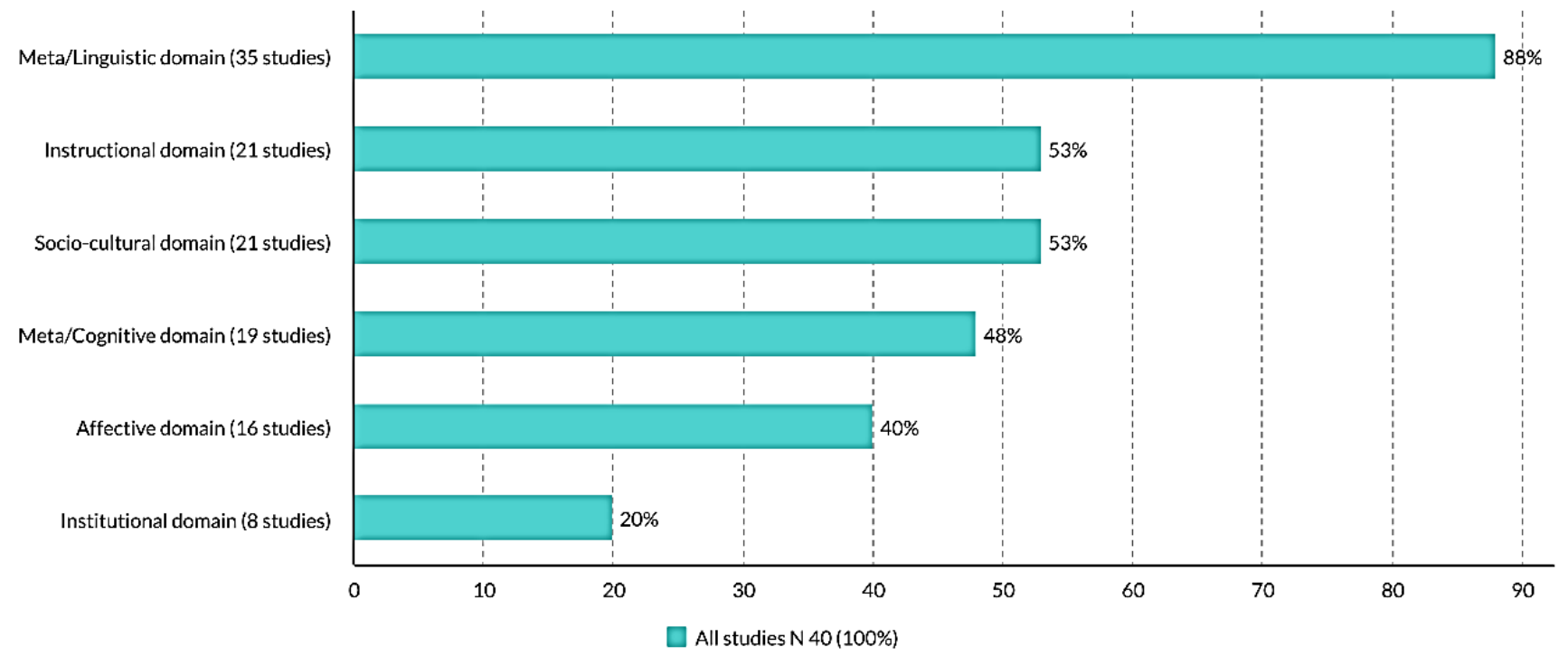

Figure 5. Distribution of studies across six analytical domains.

Next, we examined a group of themes related to students' and lecturer's English proficiency, the strategies used, and their effects on learning. For both home and international students in at least 12 studies, concerns stemmed from adapting to a bilingual academic environment in which students had low general English proficiency. Students believed that their inadequate English was one of the leading causes of poor content comprehension $[6,12,64,66,78]$, and as such this had a negative effect on their confidence 'to speak in front of classmates' $[6,79]$ and their motivation to learn [82]. Many students pointed to the weaknesses of their academic English skills and attributed it to the lack of prior experience with English Medium Instruction [6,76,82]. Students' use of coping strategies such as 'looking for gestures, some verbs, some phrases' in order to understand lecturers' 
speech further highlights the depth of the problem [12]. The latter also seemed to influence students' preference for non-native-speaking lecturers because native-speaking faculty 'often speak too fast without realizing it' [80]. Students with higher English proficiency believed that when the class has many students with low levels of English, some professors tended to 'teach at an average level' [74].

The participants in 10 studies believed that lecturers' low English proficiency was another major hurdle for content comprehension [12,53,72,84], and that it prevented course instruction 'in a deeper way' and jeopardised class facilitation and engagement [12,84]. As some instructors were not properly trained to teach or communicate in English, this led to their committing noticeable grammatical and vocabulary errors when using spoken English [75,86]; thus, they often resorted to their L1 to teach courses [79]. Students suggested that universities should 'test teacher's levels of English' or establish 'certain language standards' for EMI lecturers to help students perform better in their EMI courses $[83,86]$. This was perceived as a two-dimensional problem, in that 'not only students find it hard to understand their teachers' English, but it may be equally hard for content instructors to understand international students' English' $[83,86]$. Another related theme pointed to the lecturers' non-standard language functions. Students referred to their inability to understand lectures due to lecturers' English pronunciation, intonation, accent, or dialect $[53,75,81,86,87]$ which 'created difficulty in comprehension and caused the loss of concentration after $15 \mathrm{~min}$ of listening' [75]. The lecturers' accent especially seems to have affective and cognitive impacts on student learning $[53,67,81,88]$. On the contrary, when lecturers could successfully engage with students in 'much the same way as they do in their native language' the students mentioned that non-standard language functions became a secondary issue [87]. Some students 'felt that the use of English did not impair their ability to understand course content delivery ... due, in part, to the fact that their teachers are non-native speakers of English with more familiar accents and intonation' [53]. The latter two themes provide some context for the recurrence of a theme related to native vs. non-native English-speaking lecturer preferences $[53,71,80,88]$. In one study, Turkish EMI students chose native speakers because of 'better command of English and quality of education system', while 'better communication opportunities and better comprehension of lectures' were reasons for preferring non-native-speaking lecturers. Other students had no specific preferences, provided lecturers showed 'fluency and intelligibility' and 'expertise in the subject matter' [80]. One could also relate this theme to the lecturers' poor language awareness and support, reported in nine studies. Although in some studies students 'felt that it is not the role of lecturers to help them with English' [53], students also shared their 'dissatisfaction with an EMI class that had little language support' from instructors, and to a lesser degree, from their respective departments $[74,78,83,89,90]$. In most other cases, students made it clear that effective learning in an EMI course is not only about the quality of content and its delivery, but also the effective use of the primary medium of instruction, and that lecturers should be aware of their use of English [68,69,78,88-90].

Twelve studies have systematically addressed extensive code-switching, which refers to the alternation between languages in a specific communicative episode in an EMI classroom, such as an oral presentation or responding to a lecturer's question [99]. On the one hand, due to their insufficient level of spoken English, lack of vocabulary knowledge or due to the difficulty of the content subject, many students welcomed the possibility of using their first language (L1) when they felt the need $[12,53,67,74-76,91]$. This practice was especially expected and tolerated when used by lecturers with unclear pronunciation and who lacked the ability to 'put everything together' in English [53,64,66,67,76,89,91]. On the other hand, extensive code-switching in class caused a backlash from international and a few home students who either did not speak the L1 (such as Spanish or Mandarin) or expected their EMI course to support their 'genuine' English learning [64,74]. In some cases, code-switching was intertwined with the act of translanguaging that brought together different dimensions of students' personal history, experience, attitudes, and identities [100]. Switching to Swedish [78] or Cantonese [6] in the EMI lecture or team project allowed 
'peer communication on a different level' and 'to join the 'elite' group' of L1 speaking students' [78], or, conversely, was used by home students to disregard the needs of minority international students [6]. Indeed, the interrelationships between language fluency and codeswitching/translanguaging are not always linear. However, one can observe implications stemming from lecturers' and students' 'abandonment of English' in an EMI course altogether, preferring extensive use of $\mathbf{L 1}$ in the classroom instead, as reported in some studies $[13,65-67,78,90]$.

Finally, we explored themes related to specific problems in an EMI classroom that exposed students' problems and necessitated student-centred interventions. Students in nearly half of the studies had encountered problems with speaking and oral presentation in English, which affected their learning in various ways. The data specifically highlighted problems related to the lack of skills to 'speak in English in class' [12,66,68,91], participation in discussions [53,66,74,82,91], answering questions in English [12,52], pronunciation and peer reactions [68], 'finding the right word' [53], memorizing slides [81], 'producing absurd sentences' [12], and switching to L1 when unable to express an idea in English [74]. Some lecturers' poor English and/or monologic teaching did not provide opportunities for practising speaking skills [64]. Students also mentioned that universities provided help with English writing skills, but there was no support for oral communication [89]. Some students attributed their poor speaking to cultural norms that encouraged more 'listening' than 'speaking and arguing' in class [73,81], whereas others felt 'pressured by peers and teachers to participate in discussions' due to their higher English fluency [6]. Students believed that oral participation played a key role in their acceptance in the peer group [92]. Another critical issue for many students was inadequate English vocabulary (10 studies) which manifested itself in specific issues such as understanding vocabulary used in the class, understanding themes, inferring vocabulary from context, decoding vocabulary while listening, remembering key vocabulary, and the need to constantly look up vocabulary using dictionaries and translation tools $[12,13,65,68,90,91,93]$. Another related subtheme that emerged pointed to the problem of academic writing in English (nine studies) which could be seen from poorly written assignments [90], students' inability to compose longer essays [81], their weak knowledge of referencing and plagiarism-avoidance practices [6,81], and confusion caused by 'different requirements at a new university' [82]. Students pointed to various aspects of academic writing that presented a challenge, including format, structure, grammar, presentation, choice of words, and clarity $[65,72,83,90,91]$. Some mentioned the 'need to do research, a lot of analysis, and discussion' [6].

Eleven studies have systematically reported instances of students facing problems with EMI lecture comprehension. Namely, students had trouble when prioritizing listening and/or taking notes at the same time [12,91], with lecturer's speech rate being too fast $[75,91]$, in addition to learning and revising content that required more time, prolonged concentration, and additional energy compared with studying courses in the students' native language $[52,53,81,82]$. Other factors included lecturers failing to explain terms or not adequately using discourse markers and logical connectors $[75,86,88]$, as well as inability to comprehend and reflect on course materials in English [81]. Some students, especially those with no prior EMI experience, seemed to be especially worried about their comprehension in the first few weeks of their courses [81]. Poor lecture comprehension seems to be linked with incomprehensibility of instructions and tasks during examinations as well [66]. The use of comprehension strategies such as recording and listening to lectures several times [53], extensively using online translation tools [90], taking elaborate notes [12], printing out PowerPoint slides, and checking unfamiliar words and spelling $[81,82]$ point to the students' needs to cope with these problems on their own. Some other themes, such as bilingual instructional materials, could also relate to the problem of EMI lecture comprehension and course performance $[12,13,53,65,67,79]$. As some English textbooks and handouts were 'wordy and complex' [67], and as 'understanding a new concept in written English takes a bit longer and you have to read a sentence more than once' [53], students would prefer reading additional materials in their native language 'to gain in- 
depth knowledge of the subject contents delivered in English' [13]. However, in some settings where students were more fluent in English, they 'preferred reading authentic rather than simplified or abridged materials' in English [53]. In addition, some students were critical about 'an imbalance in the use of teaching materials' [79], in other words, lecturers' overreliance on textbooks disregarded the students' need to support learning with additional teaching materials such as videos.

\subsection{Instructional Domain}

This domain includes themes related to students' views of content lecturers' competencies and the instructional strategies used in EMI classrooms. Data extracts from 21 studies (53\%) were synthesised into six themes. The most prevalent theme within the domain is related to students' frustration with 'monologic' [84,87], non-interactive lecturing, which negatively affected students' concentration, motivation and learning in an EMI classroom $[6,12,52,53,64,67,79,84,86]$. According to students, the EMI courses did not result in any learning when the classes were 'teacher-fronted' with 'little opportunity to communicate with either teachers or peers' [67], especially when 'teachers narrated exactly what has been written in the textbooks' or 'just read from the PowerPoint slides that had already been uploaded to the Moodle $[6,12,64,79,84,86]$. Such an instructional approach had rendered 'the class atmosphere completely dead' [52]. Students were often disappointed to have 'little or no discussions in class' [86]. Such monologic teaching styles were often described by students as 'traditional,' 'dull,' 'one-way delivery', 'teacherfronted', or 'not internationalised'. [67,79,84]. Monologic instruction encouraged resistant behaviours, such as sleeping in class, using smartphones, chatting, and absences $[52,84]$. International students and some home students faced the need to adapt to classes that were more didactic and less interactive compared to what they had previously experienced [6]. Therefore, many students stressed the effectiveness of dialogic instruction, such as when lecturers encouraged informal discussions or 'faced the students and kept them busy with questions [87]. Students referred to this approach as 'useful,' 'active' 'engaging,' and 'interactive' [64,84]. Students especially praised the use of group work and other strategies for classroom management and participation that compensated for the low language proficiency of lecturers and students [64]. Although there were students who thought that the interactive nature of the classroom represented a stark contrast with their prior education experiences, nonetheless these students did not necessarily consider it an instructional deficiency [6], pointing yet again to their own lack of oral communication skills. In addition to 'interactive lecturing' students also favoured 'clear' presentation of slides and explicit communication of each lesson's objectives [87].

Along with lecturing style, students were also concerned with assessment issues when attending EMI content subjects ( 10 studies). In some cases, students found it 'stressful' that subject learning through EMI 'might have an influence on their final marks because they have difficulties to express themselves in English' $[53,64]$ and some suggested that tests and exams should be flexible in allowing the use of students' L1 [64,66]. Generally, students expected that formative and summative assessments should 'obviously ... assess subject knowledge rather than knowledge of English' [53]. Occasionally, students felt it was unfair that the examinations in English 'cater only for students who have either English-medium background or have good command over the language' [66]. This was a serious concern 'when classroom participation was part of the assessment criteria' [6]. In other cases, students pointed to difficulties with lecture comprehension and the lack of 'room for negotiating grades' when lecturers did not speak students' L1 [88]. The need to constantly use L2 also negatively affected the time management of some students for exam and graded assignment preparation [72]. Students who worked hard to complete their courses in English also expected to receive reports that certified their English proficiency in order to help them secure competitive jobs [67]. Students stressed the need for clarity and comprehensiveness, especially when lecturers' English was not advanced [65,78]. Assessment issues were also raised in other contexts. On one occasion, students were 
concerned that their peers' poor English explained the lecturers' use of 'easy' and 'nonchallenging' assessments [84]. In the same study, students pointed out that when lecturers failed to 'demonstrate relevancy' of the content, learning was reduced 'merely to surviving in examinations' [84]. Some students struggled to come to terms with many assessment varieties, such as 'a mid-term test, a group project, an online discussion' or often 'heavily weighting towards written examinations' which was too much of a burden, especially when students had no prior experience [6].

Students also felt that because a typical EMI course brings together students from all kinds of linguistic, cultural, and educational backgrounds, attending to students' diverse needs and abilities when teaching course content would significantly enhance learning outcomes $[6,12,52,79,82,84]$. In one study, students pointed out that less proficient learners thought that 'they do not receive the attention that they need from the lecturer' [52]. In the perfect scenario, students expected that the 'lecturers would listen to the students' problems and advise and help in finding solutions whenever possible, encourage and appreciate their efforts, extend deadlines for the submission of assignments, respond positively to students' weaknesses, and take care of each student individually ... ' $[12,79,82]$. Students believed that EMI programmes should be designed to 'offer flexibility in choice of courses and cater to students who learn at different paces' [79]. Students also stressed the need for lecturers to attend to students' personal and cultural sensitivities $[6,73,82,83]$. Some international students with higher levels of English 'felt the pressure to speak in class when they have nothing to say' [73]. This study pointed out that some lecturers indeed ignored 'the fact that international students desire to remain silent at times and that some [home] students do develop a desire to speak.' In another study, it was reported that the 'lecturer publicly ridiculed the Rwandan students, indicating that they did not deserve to be studying' on the programme for their poor critical thinking skills [82]. The disregard of cultural sensitivity in a multicultural EMI classroom may indeed lead to students' attrition, as one Japanese student in South Korea had experienced [83]. In addition, students in five studies mentioned the lecturers' speaking rate as a double obstacle for lecture comprehension $[12,52,75,90,91]$ reported as 'keeping up with the teacher and the topic'. The lack of clarification and corrective feedback from lecturers was another problem faced by students in five studies $[13,65,75,83,90]$. For example, some students failed to 'complete assignments without clear guidelines and rubrics' [65] or because of a lack of explanation of 'unclear terms' [75] and 'subject-specific vocabularies' [83]. As for corrective feedback, some students voiced concerns that their written assignments had many shortcomings, and the lack of feedback from lecturers only increased students' anxiety [83].

\subsection{Socio-Cultural Domain}

This domain includes themes related to students' learning in collaborative, culturally mixed and out-of-class environments. Data from 21 studies (53\%) were synthesised and grouped into seven descriptive themes. One of the major recurring themes in this domain was the challenge of communication among home and international students. Although this and the following themes may not be directly related to EMI pedagogy, they significantly impact EMI lecturers' pedagogic repertoires when implementing interactive assignments. In particular, communication breakdowns between home and international students were explained by poor or non-standard spoken English $[12,77,78]$. For example, local students expressed frustration about the difficulty of understanding international students' 'heavily accented' English [77]. Conversely, both home and international students encountered difficulties 'when interacting with native English speakers due to the fast pace of discussion and use of colloquial terms' [6]. Other students complained that communication was sometimes impossible since the 'students from the same country always sat together so they could speak their own language' [79]. Language barriers also seemed to increase in-group pressures noted by students in several studies $[73,74,77,78,84,95]$. For example, some home students felt that 'international students might have used their lack of language proficiency as an excuse to seek and receive more help from teachers' [95]. 
Another critical issue that students brought forward to express their frustration when studying in culturally mixed groups was multiple and/or unfamiliar accents $[6,12,71,77,85,95]$. Studying in such environments violated some students' expectations that 'in such groups they could learn and speak standard varieties of English such as American or British English' [77]. When speaking in class it was noted that the accent, stress, intonation, and general English proficiency of some home and international students made it difficult to follow class discussions $[6,12,71,85,95]$. Some students felt that in such situations lecturers were of little help; thus, students stressed the importance of peer support $[78,82,88,95]$. For example, some students expressed their willingness to help international students, and often played an important role in bridging the gap between EMI lecturers and international students [95].

Another theme that further highlights the importance of socio-cultural factors is linked to home and international students' divergent attitudes toward class participation $[73,74,84-86]$. For instance, in one study local students sought to limit their talk in class and would rather wait until after class to talk to the lecturers privately. Such practices were alien to most international students [73], who were often 'just too active' and tended to 'dominate the class discussions' [74]. Some home students 'didn't feel comfortable competing with international students for opportunities to contribute to the discussions', which led to their gradual withdrawal [74]. Varied cultural and educational backgrounds of students and lecturers in one course had both benefits and challenges for collaborative learning and teamwork [6,78,96-98]. According to some students, one of the benefits of diversity on collaborative learning is being 'freer' to express one's opinion 'because another person's ideas might be way crazier than yours' [97]. On the other hand, some students reported difficulties when collaborating with students with different personalities, which manifested itself in 'frustration over free-riders or a perception that some group members would not pull their weight in completing the required tasks' [6]. For example, some international students perceived that their higher English proficiency was used in an instrumental way by home students to pressure them to take the lead in finalizing a team project [6].

Finally, one of the important recurring themes within the socio-cultural domain was out-of-class learning, reported in at least eight studies $[6,13,53,65,79,81,90,93]$. An important aspect of this related to learner autonomy, i.e., the challenges of adapting to what students referred to as an 'independent learning culture' at English-medium universities [6]. These students reported being previously more accustomed to close relationships with lecturers and peers, but in the absence of these 'core sources of information and advice' they had to cope with day-to-day learning on their own $[6,81,93]$. Some students stressed that when universities offered a mentoring support, these sessions tended to be rather ineffective [79]. As a result, some students actively sought outside help (e.g., 'a ladder to climb' [81]) from former classmates, friends and family members in order to cope with difficulties studying content subject in English [65,81].

\subsection{Meta/Cognitive Domain}

This domain focuses on themes related to students' cognitive and metacognitive affordances for EMI content subject learning and comprehension. Findings and quotes from 19 studies (48\%) have been synthesised and categorised into six themes. Given the complexity of studying content subjects in L2, students in at least 11 studies $(28 \%)$ pointed to the problem of processing and comprehension of difficult content. Some students suggested that the concepts were 'too overwhelming and difficult' not only for students to learn [79], but even for lecturers to teach [53]. In many studies, students believed that compared with regular classes in L1, taking an EMI course 'required extra effort, more work and time' for students [68,69], while during classes 'keeping up with the teacher and the topic,' 'understanding lecture content in English,' 'lacking examples to scaffold understanding abstract concepts', 'lecturer not explaining the new concept' or failing to grasp when 'the lecturer starts a new idea and where they finish it' $[12,75,84]$ proved 
stressful and challenging. The most widely used strategy to 'keep up with the course' was to use the L1 as much as possible for notetaking, clarifications, cross-checking, and discussions [76].

One of the factors that further complicated the processing of new or difficult concepts was students' poor background knowledge or schema building [52,53,88,91] especially in the fields of STEM subjects, psychology [52,91], and various research methods. The students' experiences suggested that lecturers should have taken into consideration not only learners' prior EMI experiences or English proficiency levels but also their current subject knowledge [88]. On the other hand, when it came to students who had stronger background knowledge and advanced English levels, the problem turned out to be a perceived over-simplification of content by lecturers [74,84,88]. Since lecturers were aware of their own and most students' problems with English [88], they seemed to have simplified the course delivery and materials, resulting in 'easy' and 'non-challenging' lectures, discussions, and exams [84]. This sparked frustration and resistance from students with advanced background knowledge and language skills [74,84].

Another hurdle related to this cognitive domain and reported by students was the lecturers' extensive use of technical language (reported in seven studies). Students complained that when they encountered technical jargon 'everything became confusing' and 'challenging', partly because 'they had not learned technical terminology in their English language support classes' [72,94]. In the absence of support from lecturers, students sought to employ their own strategies, such as guessing from context, regularly using technical dictionaries and Wikipedia, and searching for visual descriptors [12], all of which negatively affected their overall time management and planning for thorough reading of course books or completing other assignments $[6,88]$. According to students, another barrier to effective comprehension of content was the lack of practical demonstration and/or application of knowledge by content lecturers, as reported in three studies. Since many students seemed to have 'prioritised disciplinary learning' [67] 'acquiring content knowledge and being able to put it into practice' was the most essential perceived learning outcome [84]. However, according to students, and partly due to lecturers' language deficiencies or monologic lecturing, practical demonstration or application of course content was not possible, which increased students' dissatisfaction and disengagement $[67,74,84]$.

Finally, one emerging theme that negatively affected engagement, especially during seminars and discussions, was students' poor rhetorical and critical thinking skills [6,83,97]. Students pointed to their lack of prior training in criticism and content discussion (e.g., 'grasping and reflecting on author's reasoning and proposing alternative methods/perspectives') during lectures, presentations, team projects, and when writing essays [97]. Some students believed that lecturers' teaching style by default limited the opportunities for participating in 'engaged and argumentative' [6] as well as 'discussion-centred' sessions [83].

\subsection{Affective Domain}

This domain includes themes related to students' socio-emotional and motivational responses toward EMI. Data from 16 studies (40\%) were synthesised and grouped into 10 descriptive themes. Students in at least six studies reported a lack of confidence when taking EMI courses $[12,13,52,64,79,82]$. Specifically, they felt 'shameful' about their poor spoken English, resulting in their avoiding communication with teachers and peers [12,13,52,79]. In some situations, even when students were 'courageous enough' to overcome their shyness and participate in discussions, the 'one-way teaching environment' undermined such efforts [82]. Although many themes in this domain were closely intertwined, some themes, such as fear of losing face [12,13,64,68,74], were strongly linked to one another. This theme covered situations when students were to interact with native English-speaking lecturers [12,13] and present or speak in front of the class [12,74], as well as with problems of pronunciation [68] and perceived overall ability 'to get through' the course [64].

Fear of losing face in the context of communication among students with poor English and their native English-speaking lecturers seemed to negatively affect the building of 
teacher-student rapport [13,95]. Students expressed their frustration [6,12,64,74,79,95] with having to follow local cultural norms and refrain from disagreeing with faculty [95], or being required to attend courses with poor relevance to their academic majors [74,79], with poor comprehension of content in English, with having to collaborate with other students [6] with lower English proficiency [64], and with lectures being too 'teachercentred' [6]. Although the level of student dissatisfaction with the EMI courses fluctuated from study to study, some articles reported increased dissatisfaction due to linguistic, instructional, and socio-cultural reasons $[68,74,79,84,87]$. Elevated anxiety and stress were explicitly reported in five studies $[6,52,64,68,81]$ when students felt anxious and stressed at the beginning of the course [81], and when 'speaking in public' or answering questions in English $[52,68]$. Stress levels due to perceived poor English skills were heightened during major summative assessments [64], when reading difficult course materials [6], or when trying to come to terms with lecturers' strong accents [81]. Some students also reported an increased sense of boredom when lecturers conducted monotonous classes and when topics were either non-challenging or irrelevant to students $[12,52,84]$. Some students thought that fatigue was 'a typical state of body and mind' when attending classes on complex topics in a foreign language [12,52], especially when there was no break [52]. Related to the affective domain, students explained their participation in EMI courses by intrinsic motivation $[13,65,66,68,84]$.

Despite having low levels of English, they sought to attend EMI courses and interact with their teachers and 'like-minded peers' [84] as a way 'to boost their academic learning' [13], 'to improve their language skills' and 'to maintain the international standards' $[66,68]$. They also 'proactively and creatively developed coping [strategies] that worked for them' [65]. However, some students' interest in the course and motivation to learn were negatively affected when lecturers did not demonstrate linguistic fluency and pedagogical competence [66]. Data also pointed to the presence of extrinsic motivation $[12,53,68,84]$ to explain students' desire to attend EMI courses. In some studies, students believed that EMI experience would better prepare them for future jobs at multinational companies and the growing role of English in the world [12,53,68,84]. In other cases, they took up the courses because of their 'friends who were enrolled in the same classes,' 'because parents insisted' and due to a perceived need to 'take an internship abroad and become an Erasmus student' [68].

\subsection{Institutional Domain}

This domain includes themes related to university-wide policies and conditions affecting learning in EMI classrooms. Compared to the previous five domains, the institutional needs were less evident in student responses. Eight studies (20\%) in total referred to these needs, which were then synthesised and grouped into three themes. Somewhat implicitly, students mention ineffective curriculum design and planning in their universities $[74,79,82,87]$ as affecting the ways in which EMI classes were conducted and classroom experience was affected. Some students stressed that compulsory EMI courses did not take into consideration students' content needs and language levels, thus increasing disengagement $[74,79]$. The courses were designed and delivered with the expectation that all students would successfully cope with the linguistic and academic aspects, which often proved incorrect [82]. Some students complained about poor communication channels (often in local languages) regarding the courses offered [79].

Another theme focused on inadequate self-access support $[53,82,89,93]$, i.e., access to facilities and programmes organised by home institutions to help students improve their academic English skills. Some students were 'critical of the lack, or limited availability' of support centres or classes [82] and, when available, of the relevance of these to their needs [89]. Although many students were already too overloaded with their EMI classes and assignments to attend additional classes, some students felt the need to attend such programmes improved their composition and spoken English skills [53,93]. 
Finally, like support centres, some of the English for Academic Purposes (EAP) courses did not address students' needs [13,82,89]. For example, some students complained these courses were 'irrelevant' and 'of little value' because lecturers taught the courses in English in the same way other content classes were taught [13,89], or 'used methodologies that did not suit the beginners' [82]. Overall, even from this limited number of studies a strong connection can be seen between institutional policy implementation and classroom experiences.

These findings highlight several crucial factors which might affect the ways in which learner-centred EMI is researched and practiced in the future. This synthesis suggests that the process of adopting learner-centred EMI pedagogy may not be as uniform and standardised as one might to expect.

\section{Discussion: Empirical and Pedagogical Implications}

The aim of this study was to identify the challenges to the implementation of learnercentred EMI pedagogy by synthesizing and analysing student experiences as reported in primary qualitative research. The findings reveal that teaching practices and learning environments can create obstacles to promoting learner-centred experiences in the EMI setting. These obstacles are summarised and presented in Figure 6. Five factors are further discussed in this section: (1) context-dependency; (2) multi-dimensionality; (3) domain interdependence; (4) teacher-centredness by default; and (5) sustaining the effectiveness of EMI on all levels.

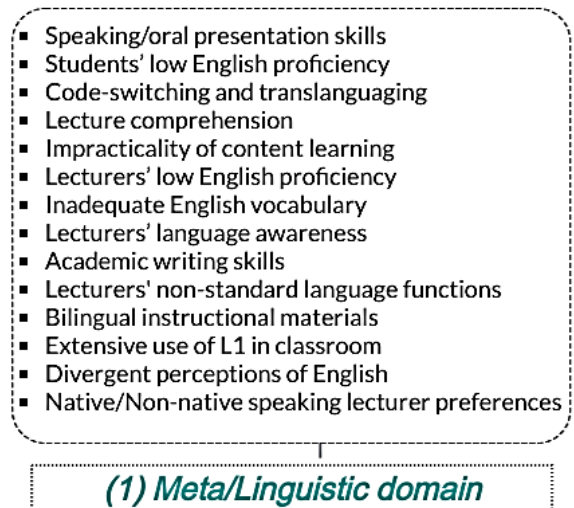

- Monologic, non-interactive lecturing

- Assessment issues

- Non-attending to students' diverse needs and abilities

- Lecturers' speaking rate

- Insufficient clarification and corrective feedback from lecturers

- Non-attending to students' personal qualities and cultural sensitivities
- Communication among home/ international students

- Out-of-class learning environment

- Multiple / unfamiliar accents

- In-group pressures

- Divergent attitudes toward class participation

- Peer interaction

- Collaborative learning and teamwork

(2) Instructional domain

(3) Socio-cultural domain

Obstacles to implementing learner-centered EMI pedagogy from students' perspective

\begin{tabular}{|c|c|c|}
\hline \multirow{2}{*}{\multicolumn{3}{|c|}{1}} \\
\hline & & \\
\hline (4) Meta/Cognitive domain & (5) Affective domain & (6) Institutional domain \\
\hline $\begin{array}{l}\text { - Processing and comprehension of } \\
\text { difficult content } \\
\text { - Extensive use of technical language } \\
\text { - Insufficient background knowledge } \\
\text { (of content) } \\
\text { - Poor rhetorical and critical thinking } \\
\text { skills } \\
\text { - Lack of practical demonstration } \\
\text { and/or application of knowledge } \\
\text { - Over-simplification of content }\end{array}$ & $\begin{array}{l}\text { - Confidence } \\
\text { - Frustration } \\
\text { - Fear of loosing face } \\
\text { - Dissatisfaction } \\
\text { - Anxiety and stress } \\
\text { - Intrinsic motivation } \\
\text { - Extrinsic motivation } \\
\text { - Boredom } \\
\text { - Fatigue } \\
\text { - Teacher-student rapport }\end{array}$ & $\begin{array}{l}\text { - Ineffective curriculum design and } \\
\text { planning } \\
\text { - Poor self-access support } \\
\text { - EAP courses not meeting students' } \\
\text { needs }\end{array}$ \\
\hline
\end{tabular}

Figure 6. Summary schema of analytical domains and descriptive themes. 


\subsection{Context-Dependency}

Perceived obstacles to the implementation of learner-centred pedagogy vary between countries, institutions, disciplines, and teacher and student bodies. For instance, while some studies explained EMI's 'dynamism and context dependency' by reference to institutional factors [29,89], other studies associated it with differences in lecturer profiles (e.g., age, experience, English proficiency, subjects taught, country of residence) and, crucially, access to faculty development and EMI certification [47]. EMI's context-dependency is reflected especially vividly in the differences among student experiences and perceived challenges across classrooms in different countries and jurisdictions $[40,49,50,55,78,96,101]$. While researchers stress the importance of 'context-sensitive ways to implement EMI' and 'EMI curriculum innovation' amidst growing multilingualism in HE [16,89], an important question that remains to be tackled by future research is: whether, in the absence of clear goals and objectives due to the varying contexts, conceptualisations and purposes of EMI among faculty and students, learner-centred pedagogies can be sustainably implemented in diverse EMI classrooms around the world, and if so, how is this to be accomplished?

While answers to this question will depend on the extent and targeted nature of future studies (i.e., by using learner-centred pedagogy as their primary focus, which is scarce in the current EMI literature), we are nonetheless beginning to understand that the high contextuality of EMI is a natural and an inevitable process and not necessarily an impeding issue for EMI's success. Evidence from the studies synthesised here suggest that every one of the six analytic domains could also be seen as a 'different context' and could serve as a blueprint for implementing learner-centred pedagogy along with promoting teacher training, certification, and pre-enrolment support programmes for students $[43,46,102]$.

\subsection{Multi-Dimensionality}

The six suggested domains are multiple dimensions of EMI pedagogy, which is supported by related studies [7,54,103-109]. For example, Macaro's measures of quality interaction in pedagogy place emphasis on the meta-linguistic aspects of interaction (e.g., the use of a wide variety of teacher language functions), while the remaining four measures seem to have been designed as instructional (e.g., extended Initiation-Response-Feedback) as well as (meta)cognitive interventions (e.g., teachers posing questions that require highlevel cognitive responses from students, allowing long student turns to help them express higher-level concepts, and giving students sufficient time to allow the thinking process to occur). In addition, lecturer-student and student-student interactions in the EMI context indeed transcend linguistic and metacognitive territories [54,103-106,110], and may be closely linked to other realms such as the socio-cultural and affective [50,108,109,111-114]. For example, several studies explored Asian university students' perceptions of their reluctance in verbal EMI classroom participation, often claiming shyness and poor speaking skills as key determinants $[55,115]$. It was found that such students used silence as a tool to quietly yet attentively participate and 'as a way to harmonise with the environment which is the cultural norm' in their countries [55,115]. Our synthesis reveals that all dimensions related to learner-centred EMI pedagogy might need equal attention, since some are still less well-researched than others. In particular, future studies should examine the impact of socio-cultural, (meta)cognitive, affective, and institutional issues which, according to students, affect their EMI learning experience.

Moreover, most studies thus far have focused on investigating how linguistic and meta-linguistic issues impede student learning in EMI and highlighted the importance of English proficiency for both lecturers and students. This demonstrates how critical the ' $E$ ' is in successful implementation of learner-centred pedagogical EMI $[9,14,44,78,116]$. This is echoed by growing research in language comprehension (e.g., how linguistic and metalinguistic ability affects student learning). However, this also means that other factors of the learning environment such as meta/cognitive, instructional, affective, socio-cultural, and institutional factors have been somewhat neglected and need to be studied in much more depth. 


\subsection{Domain Interdependence}

While our synthesis identified six broad domains, their analysis exposed numerous connections between the domains. Domain interdependence is also evidenced by the quotations from students, which often fitted more than one domain. This indicates that learner-centred EMI pedagogy can be understood as a dynamic web of domains which are closely intertwined and affected by one another; Figure 7 provides a sample schema to support this view. From the diagram, one can see that the socio-cultural and affective domains may well be impacted if the institutional domain has not created adequate conditions to prepare students linguistically and cognitively to enroll in EMI courses or, for the same reasons, not trained lecturers to deliver learner-centred classroom experiences.

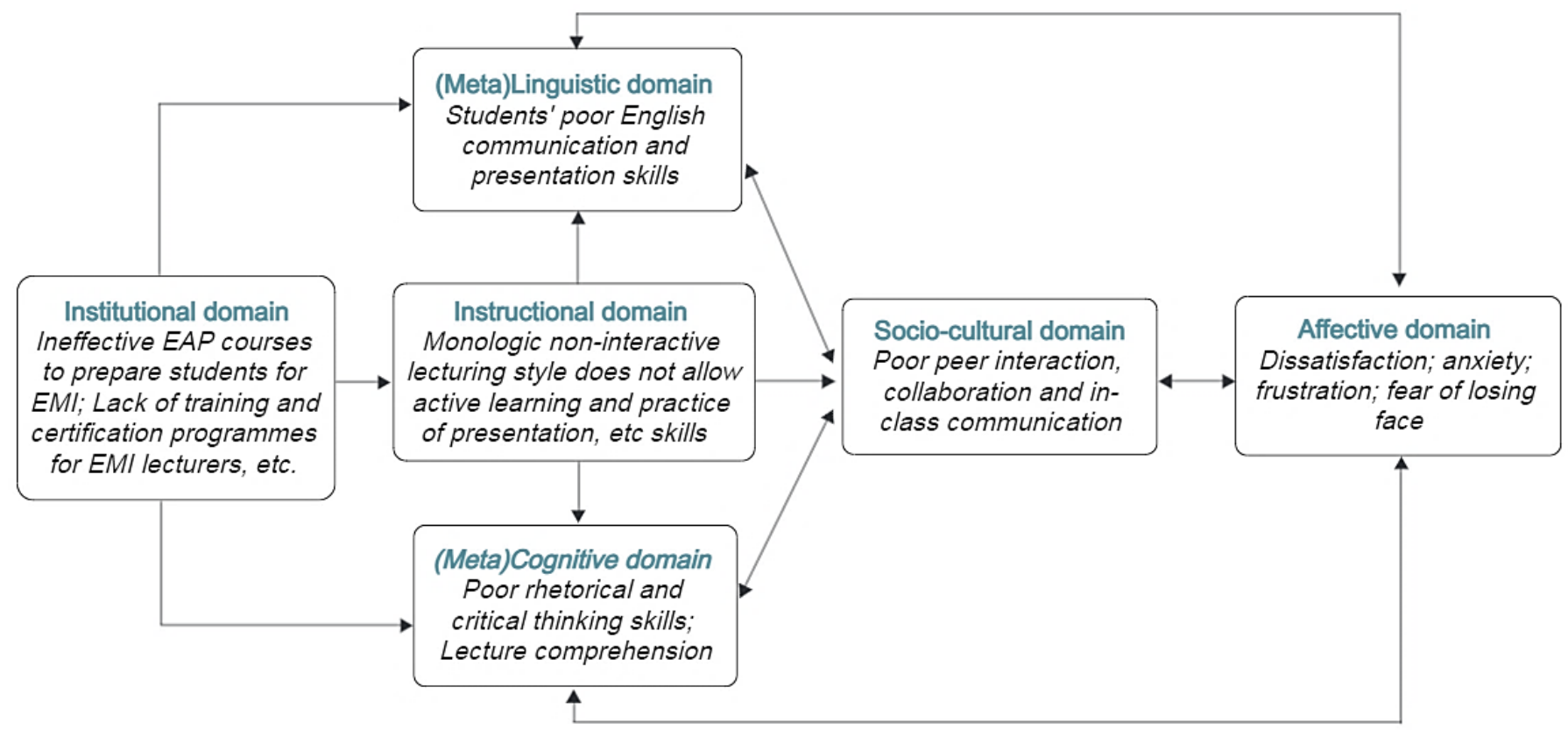

Figure 7. A sample schema of interdependence among domains and themes.

In addition, while observing various ways in which the reviewed studies labelled and classified students' perceived obstacles to implementing learner-centred pedagogy in EMI, we found that the content of quotations from the different studies were often similar, suggesting that despite varying geographic and institutional contexts [5,51] students often voiced similar experiences and concerns $[6,12,64,84,86,87]$. This strongly suggests that even under very diverse interpretations of EMI there is something universal in the expectations of learner-centred experiences for students taking EMI content courses.

\subsection{Teacher-Centredness by Default}

This study found that despite growing awareness in recent years among EMI scholars about the needs and anxieties of students attending EMI courses in HE, in most of the reviewed contexts English Medium Instruction continues to be associated with a teachercentred learning experience. One possible explanation is that, by default, many EMI lecturers in the selected studies prioritise transmitting content knowledge primarily through monologic lectures, in some cases with limited classroom interaction $[12,30,52,53,64,67,79,84]$. Participant students in the reviewed studies voiced their concerns with teacher-centred classrooms and the fact that the quality of their learning was evaluated based on their ability to correctly reproduce knowledge provided by teachers $[6,65,66,72,78,84,88]$. This synthesis has found strong evidence pointing to lecturers' overuse of didactic modes of teaching and the resulting negative impact on the (meta)cognitive, affective, and socio-cultural aspects of students' content learning in English. 
It is understandable, given the nature of EMI courses with a focus on content delivery rather than language learning and the fears that lecturers have about their own language proficiency, that lecturers may tend to fall back on a monologic approach. Teacher-centred pedagogies have traditionally been associated with formal and hierarchical relationships among lecturers and students [36,117,118], with students perceiving themselves as the 'consumers' and lecturers as the 'providers' of knowledge [52,53,66,90,91,119,120]. However, it is clear that EMI institutions and lecturers need to find effective solutions in order to integrate learner-centred pedagogy into EMI course design and delivery.

\subsection{Sustaining the Effectiveness of EMI on All Levels}

Finally, our results have implications for sustaining the effectiveness of EMI on three levels:

1. On a micro-level, the success of both HE internationalisation and EMI pedagogy depends on how effectively such programmes can create inclusive environments to sustain students' learning, motivation, and classroom engagement. As we observed from numerous studies, even 'small' issues such as 'fear of losing face' or 'multiple accents in multicultural EMI classrooms' can impair student learning and satisfaction in the long run when not addressed [13,68,77,95].

2. On a meso-level, implementing an effective and learner-centred EMI pedagogy requires a sustainable institutional strategy to train and possibly certify content lecturers. Crucially, such measures could also focus on facilitating collaboration and coordination between content lecturers and language instructors in a systematic manner [3-6].

3. On a macro-level, the success of EMI ultimately depends on how faculty and university administrators perform on the previous two fronts, as they are critical for sustaining international student mobility and inter-university partnerships as strategic objectives of the internationalisation of $\mathrm{HE}$ [2].

\section{Conclusions}

\subsection{Overview of Findings}

This synthesis has confirmed the findings of previous research in that many students believe in the usefulness of the EMI experience in terms of gaining new content knowledge, enhancing English language skills, and improving the chances of future employment and career growth. The key obstacles to such successful participation can be categorised into many themes, including teacher-centred pedagogical approaches, lack of language awareness by lecturers, and students' own unpreparedness to effectively participate in EMI courses, among many others. The findings of this synthesis are consistent with previous studies that highlight the critical role of language and academic skills from the perspective of both students and lecturers [9-11], as well as the need for dialogic, interactive, and multimodal pedagogical approaches in order to ensure the effective implementation of EMI [7,42,56,121,122].

Consequently, this study has made several important contributions to the literature on EMI. First, by synthesizing qualitative evidence, we have identified six types of challenges for implementing learner-centred EMI pedagogies across diverse geographic and institutional contexts. Second, this study discussed five strategic points which EMI faculty and administrators can use to design effective interventions, improve student satisfaction, and promote the internationalisation of university programmes. Third, the study has found many micro-level pedagogical issues within these six domains, some of which require further research and validation. Finally, this study contains useful implications with regard to sustaining the effectiveness of EMI on three levels in the context of HE internationalisation.

\subsection{Strengths and Limitations}

An extensive primary qualitative literature search was conducted in order to achieve the study's goals. In addition, this is the first study to use a systematic thematic synthesis of primary qualitative research to examine students' views and experiences of EMI. The review process was transparent, systematic, and included empirical studies from a variety 
of academic subjects and geographies. Furthermore, rigorous article eligibility criteria allowed for stronger internal validity. We thoroughly followed the ENTREQ, CASP and COREQ protocols in conducting this synthesis.

However, since we did not attempt to stratify our findings using various EMI models and typologies such as different purposes of EMI, diverse curriculum models, EMI introduction and access models, etc. $[7,28,30]$, the findings of this study may not be readily applicable to specific EMI contexts. Therefore, future review studies in specific and unique contexts may be warranted. Additionally, while the overall findings from this synthesis are based on insights gathered from a large sample of 1769 university and college students in 20 countries and jurisdictions, the findings from several articles included in this review were themselves limited by small sample sizes $[74,78,84,85]$.

Another limitation of this study is that all 40 studies that met the inclusion criteria were primary qualitative studies (i.e., they used in-depth interviews, classroom observation, focus groups, student journals, and open-ended surveys as their primary data). In doing so, our study has strictly followed the guidelines [63]. However, since the term 'primary' remains ill-defined in this context, we excluded papers $(N=61)$ which used mixed methods even though they featured smaller-scale interviews and focus groups to triangulate their primary quantitative results. Since several previous synthesis studies in other fields have included mixed methods studies [123,124], future EMI synthesis studies might consider adopting a similar approach.

Finally, the samples from the included studies were selected from very diverse student populations, covering both home and international students as well as those studying in undergraduate, graduate, postgraduate and doctoral EMI programmes. Although we recognise that this diversity of respondents and samples may affect the characterisation of challenges for the implementation of learner-centred pedagogy, our aim was to define the commonalities among this diverse population. Therefore, we focused on the content of respondents' quotations, not their personal characteristics. Given that diverse populations were included in the synthesis, we are convinced that our findings cover a wide range of student views on the challenges in implementing learner-centred EMI.

Author Contributions: Conceptualisation, M.I.; writing—original draft, M.I.; methodology, M.I., T.K.F.C. and J.D.; data curation, M.I., Y.Y. and N.D.; visualisation, M.I.; software, M.I.; investigation, M.I. and T.K.F.C.; writing-review and editing, M.I., T.K.F.C., J.D. and Y.Y.; project administration, M.I. and Y.Y.; funding acquisition, M.I. All authors have read and agreed to the published version of the manuscript.

Funding: This research was funded by the Japan Society for the Promotion of Science (JSPS) Grantin-Aid for Scientific Research Category C; number 21K00701.

Institutional Review Board Statement: Not applicable.

Informed Consent Statement: Not applicable.

Data Availability Statement: All data presented are available in the paper.

Acknowledgments: The authors would like to thank two anonymous reviewers for their helpful suggestions and comments.

Conflicts of Interest: The authors declare no conflict of interest. 


\section{Appendix A}

Table A1. Descriptors of empirical studies included in the synthesis.

\begin{tabular}{|c|c|c|c|c|c|c|c|}
\hline \multirow[b]{2}{*}{$\#$} & \multirow[b]{2}{*}{$\begin{array}{c}\text { Author } \\
\text { Year [Ref] } \\
\text { Document Type }\end{array}$} & \multirow[b]{2}{*}{ Location } & \multirow[b]{2}{*}{$\begin{array}{l}\text { Sample Size, } \\
\text { EMI Subject }\end{array}$} & \multirow[b]{2}{*}{$\begin{array}{c}\text { Design (Data } \\
\text { Collection; Data } \\
\text { Analysis) }\end{array}$} & \multirow[b]{2}{*}{$\begin{array}{c}\text { Key Research } \\
\text { Question(s) }\end{array}$} & \multicolumn{2}{|c|}{ Quality Appraisal } \\
\hline & & & & & & $\begin{array}{c}\text { CASP } \\
\text { 10-Item } \\
\text { Check List } \\
\text { [60] }\end{array}$ & $\begin{array}{c}\text { COREQ } \\
\text { 32-Item } \\
\text { Check List } \\
\text { [61] }\end{array}$ \\
\hline 1. & $\begin{array}{l}\text { Alhassan et al. } \\
\text { 2021 [91] } \\
\text { Journal article }\end{array}$ & Sudan & $\begin{array}{c}N=21 \\
\text { Business }\end{array}$ & $\begin{array}{c}\text { Ethnographic } \\
\text { research } \\
\text { (Semi-structured } \\
\text { Interviews, } \\
\text { observations, and } \\
\text { collection of } \\
\text { documents; Content } \\
\text { analysis). }\end{array}$ & $\begin{array}{l}\text { What challenges do } \\
\text { Sudanese EMI } \\
\text { business students } \\
\text { experience in EMI } \\
\text { courses? To what } \\
\text { extent do these } \\
\text { problems impact } \\
\text { students' academic } \\
\text { performance? }\end{array}$ & Passed & Passed \\
\hline 2. & $\begin{array}{l}\text { Baker \& Fang } \\
2020[98] \\
\text { Journal article }\end{array}$ & $\begin{array}{l}\text { Mainland } \\
\text { China (and } \\
\text { UK) }\end{array}$ & $\begin{array}{c}N=45 \\
\text { Various EMI } \\
\text { courses }\end{array}$ & $\begin{array}{c}\text { A qualitative } \\
\text { interpretive design } \\
\text { (Open-ended } \\
\text { questionnaire } \\
\text { responses, interviews } \\
\text { and focus groups; } \\
\text { Thematic framework } \\
\text { approach). }\end{array}$ & $\begin{array}{c}\text { To what extent do } \\
\text { students develop an } \\
\text { awareness of and/or } \\
\text { identity as an } \\
\text { intercultural citizen } \\
\text { because of } \\
\text { undertaking EMI } \\
\text { programmes in a } \\
\text { university abroad? }\end{array}$ & Passed & Passed \\
\hline 3. & $\begin{array}{l}\text { Chalapati et al. } \\
2018[79] \\
\text { Journal article }\end{array}$ & Taiwan & $\begin{array}{l}\quad N=64 \\
\text { International } \\
\text { tourism and } \\
\text { hospitality }\end{array}$ & $\begin{array}{l}\text { A qualitative design } \\
\text { (Semi-structured, } \\
\text { focus group } \\
\text { interviews; Thematic } \\
\text { framework } \\
\text { approach). }\end{array}$ & $\begin{array}{c}\text { What are the learning } \\
\text { experiences of local } \\
\text { and international } \\
\text { students, and what } \\
\text { barriers do they face } \\
\text { in an EMI degree } \\
\text { programme at a } \\
\text { private university? }\end{array}$ & Passed & Passed \\
\hline 4. & $\begin{array}{c}\text { Ding \& Stapleton } \\
2016[81] \\
\text { Journal article }\end{array}$ & $\begin{array}{l}\text { Hong Kong } \\
\text { SAR }\end{array}$ & $\begin{array}{l}\quad N=9 \\
\text { Various EMI } \\
\text { courses }\end{array}$ & $\begin{array}{c}\text { A qualitative } \\
\text { multiple case study } \\
\text { design } \\
\text { (semi-structured } \\
\text { interviews, classroom } \\
\text { observation; } \\
\text { Thematic framework } \\
\text { approach). }\end{array}$ & $\begin{array}{l}\text { What major problems } \\
\text { do students } \\
\text { encounter while } \\
\text { adapting to the EMI } \\
\text { education? }\end{array}$ & Passed & Passed \\
\hline 5. & $\begin{array}{c}\text { Doiz \& } \\
\text { Lasagabaster } \\
2018 \text { [68] } \\
\text { Journal article }\end{array}$ & Spain & $\begin{array}{c}N=28 \\
\text { Various EMI } \\
\text { courses }\end{array}$ & $\begin{array}{c}\text { A qualitative } \\
\text { interpretive design } \\
\text { (Focus group } \\
\text { interviews and } \\
\text { discussions; } \\
\text { Thematic framework } \\
\text { approach). }\end{array}$ & $\begin{array}{l}\text { How are teachers' } \\
\text { and students' ideal } \\
\text { L2 self-manifested in } \\
\text { EMI? What are the } \\
\text { teachers' and } \\
\text { students' reflections } \\
\text { on the EMI } \\
\text { experience? }\end{array}$ & Passed & Passed \\
\hline 6. & $\begin{array}{c}\text { Doiz et al. } \\
2013 \text { [70] } \\
\text { Journal article }\end{array}$ & Spain & $\begin{array}{c}N=27 \\
\text { Various EMI } \\
\text { courses }\end{array}$ & $\begin{array}{c}\text { A qualitative } \\
\text { interpretive design } \\
\text { (Focus group } \\
\text { discussions; } \\
\text { Thematic framework } \\
\text { approach). }\end{array}$ & $\begin{array}{l}\text { What does } \\
\text { internationalisation } \\
\text { mean to the } \\
\text { university } \\
\text { community? How } \\
\text { much does the } \\
\text { community value } \\
\text { EMI? }\end{array}$ & Passed & Passed \\
\hline
\end{tabular}


Table A1. Cont.

\begin{tabular}{|c|c|c|c|c|c|c|c|}
\hline \multirow[b]{2}{*}{ \# } & \multirow[b]{2}{*}{$\begin{array}{c}\text { Author } \\
\text { Year [Ref] } \\
\text { Document } \\
\text { Type }\end{array}$} & \multirow[b]{2}{*}{ Location } & \multirow[b]{2}{*}{$\begin{array}{l}\text { Sample Size, } \\
\text { EMI Subject }\end{array}$} & \multirow[b]{2}{*}{$\begin{array}{c}\text { Design (Data } \\
\text { Collection; Data } \\
\text { Analysis) }\end{array}$} & \multirow[b]{2}{*}{$\begin{array}{c}\text { Key Research } \\
\text { Question(s) }\end{array}$} & \multicolumn{2}{|c|}{ Quality Appraisal } \\
\hline & & & & & & $\begin{array}{c}\text { CASP } \\
\text { 10-Item } \\
\text { Check List } \\
\text { [60] }\end{array}$ & $\begin{array}{c}\text { COREQ } \\
\text { 32-Item } \\
\text { Check List } \\
\text { [61] }\end{array}$ \\
\hline 7. & $\begin{array}{c}\text { Fareed et al. } \\
2019 \text { [66] } \\
\text { Journal article }\end{array}$ & Pakistan & $\begin{array}{l}N=104 \\
\text { Various EMI } \\
\text { courses }\end{array}$ & $\begin{array}{c}\text { A qualitative } \\
\text { interpretive design } \\
\text { (In-depth interviews; } \\
\text { Thematic framework } \\
\text { approach). }\end{array}$ & $\begin{array}{c}\text { What are the } \\
\text { perceptions of school, } \\
\text { college and } \\
\text { university teachers } \\
\text { and students about } \\
\text { the medium of } \\
\text { instruction? }\end{array}$ & Passed & Passed \\
\hline 8. & $\begin{array}{c}\text { Galloway \& } \\
\text { Ruegg } \\
2020[89] \\
\text { Journal article }\end{array}$ & $\begin{array}{l}\text { Japan and } \\
\text { Mainland } \\
\text { China }\end{array}$ & $\begin{array}{l}N=29 \\
\text { Various EMI } \\
\text { courses }\end{array}$ & $\begin{array}{c}\text { A qualitative } \\
\text { interpretive design } \\
\text { (Open-ended } \\
\text { questionnaire } \\
\text { responses, interviews } \\
\text { and focus groups; } \\
\text { Thematic framework } \\
\text { approach). }\end{array}$ & $\begin{array}{l}\text { What are the core } \\
\text { principles of EMI? } \\
\text { How can students } \\
\text { studying through the } \\
\text { medium of English } \\
\text { be supported? } \\
\text { What are the needs of } \\
\text { the international } \\
\text { student body? }\end{array}$ & Passed & Passed \\
\hline 9. & $\begin{array}{l}\text { Hamid et al. } \\
2013 \text { [76] } \\
\text { Journal article }\end{array}$ & Bangladesh & $\begin{array}{l}\quad N=54 \\
\text { Various EMI } \\
\text { courses }\end{array}$ & $\begin{array}{c}\text { A qualitative } \\
\text { interpretive design } \\
\text { (semi-structured } \\
\text { interviews, classroom } \\
\text { observations; } \\
\text { Inductive content } \\
\text { analysis). }\end{array}$ & $\begin{array}{l}\text { How do teachers and } \\
\text { students develop } \\
\text { language practices, } \\
\text { ideologies and } \\
\text { institutional othering } \\
\text { in a private } \\
\text { university in } \\
\text { Bangladesh? }\end{array}$ & Passed & Passed \\
\hline 10. & $\begin{array}{c}\text { Han et al. } \\
2020[95] \\
\text { Journal article }\end{array}$ & $\begin{array}{l}\text { Mainland } \\
\text { China }\end{array}$ & $\begin{array}{c}N=25 \\
\text { Various EMI } \\
\text { courses }\end{array}$ & $\begin{array}{c}\text { A qualitative } \\
\text { interpretive design } \\
\text { (In-depth interviews; } \\
\text { Thematic framework } \\
\text { approach). }\end{array}$ & $\begin{array}{l}\text { What challenges do } \\
\text { local students } \\
\text { experience when } \\
\text { working with } \\
\text { international } \\
\text { students? }\end{array}$ & Passed & Passed \\
\hline 11. & $\begin{array}{c}\text { He \& Chiang } \\
2016[86] \\
\text { Journal article }\end{array}$ & $\begin{array}{l}\text { Mainland } \\
\text { China }\end{array}$ & $\begin{array}{l}\quad N=60 \\
\text { Various EMI } \\
\text { courses }\end{array}$ & $\begin{array}{c}\text { A qualitative } \\
\text { interpretive design } \\
\text { (Open ended reports; } \\
\text { Thematic framework } \\
\text { approach). }\end{array}$ & $\begin{array}{l}\text { English-medium } \\
\text { education aims in } \\
\text { accommodating } \\
\text { international } \\
\text { students in Mainland } \\
\text { Chinese universities, } \\
\text { and how well are } \\
\text { they working? }\end{array}$ & Passed & $\begin{array}{c}\mathrm{N} / \mathrm{A} \\
\text { (No inter- } \\
\text { views/focus } \\
\text { groups used) }\end{array}$ \\
\hline 12. & $\begin{array}{c}\text { Henry \& } \\
\text { Goddard } \\
2015[69] \\
\text { Journal article }\end{array}$ & Sweden & $\begin{array}{c}N=32 \\
\text { Various EMI } \\
\text { courses }\end{array}$ & $\begin{array}{c}\text { A qualitative } \\
\text { discourse analysis } \\
\text { (Semi-structured } \\
\text { interviews; } \\
\text { Discursive analysis). }\end{array}$ & $\begin{array}{l}\text { Does identity play a } \\
\text { role in explaining } \\
\text { Swedish students' } \\
\text { enrolment in an EMI } \\
\text { programme? }\end{array}$ & Passed & Passed \\
\hline 13. & $\begin{array}{l}\text { Hino } 2017 \text { [85] } \\
\text { Book chapter }\end{array}$ & Japan & $\begin{array}{l}N=4 \\
\text { Various EMI } \\
\text { courses }\end{array}$ & $\begin{array}{c}\text { A qualitative } \\
\text { interpretive design } \\
\text { (Case studies, class } \\
\text { observation, class } \\
\text { video recording, } \\
\text { open-ended } \\
\text { questionnaire; } \\
\text { Content analysis). }\end{array}$ & $\begin{array}{l}\text { How could EMI help } \\
\text { students acquire } \\
\text { communicative } \\
\text { abilities in EIL, } \\
\text { including linguistic, } \\
\text { sociolinguistic, and } \\
\text { interactive? }\end{array}$ & Passed & $\begin{array}{c}\text { N/A } \\
\text { (No inter- } \\
\text { views/focus } \\
\text { groups used) }\end{array}$ \\
\hline 14. & $\begin{array}{c}\text { Holi Ali } \\
2020[65] \\
\text { Journal article }\end{array}$ & Oman & $\begin{array}{l}\quad N=12 \\
\text { Engineering }\end{array}$ & $\begin{array}{c}\text { A qualitative } \\
\text { interpretive design } \\
\text { (Semi-structured } \\
\text { interviews; Inductive } \\
\text { content analysis). }\end{array}$ & $\begin{array}{l}\text { How did Omani } \\
\text { engineering students } \\
\text { respond to EMI } \\
\text { challenges? }\end{array}$ & Passed & Passed \\
\hline
\end{tabular}


Table A1. Cont.

\begin{tabular}{|c|c|c|c|c|c|c|c|}
\hline \multirow[b]{2}{*}{$\#$} & \multirow[b]{2}{*}{$\begin{array}{c}\text { Author } \\
\text { Year [Ref] } \\
\text { Document } \\
\text { Type }\end{array}$} & \multirow[b]{2}{*}{ Location } & \multirow[b]{2}{*}{$\begin{array}{l}\text { Sample Size, } \\
\text { EMI Subject }\end{array}$} & \multirow[b]{2}{*}{$\begin{array}{c}\text { Design (Data } \\
\text { Collection; Data } \\
\text { Analysis) }\end{array}$} & \multirow[b]{2}{*}{$\begin{array}{c}\text { Key Research } \\
\text { Question(s) }\end{array}$} & \multicolumn{2}{|c|}{ Quality Appraisal } \\
\hline & & & & & & $\begin{array}{c}\text { CASP } \\
\text { 10-Item } \\
\text { Check List } \\
\text { [60] }\end{array}$ & $\begin{array}{c}\text { COREQ } \\
\text { 32-Item } \\
\text { Check List } \\
\text { [61] }\end{array}$ \\
\hline 15. & $\begin{array}{l}\text { Hua } 2020[52] \\
\text { Journal article }\end{array}$ & Taiwan & $\begin{array}{c}N=30 \\
\text { Psychology }\end{array}$ & $\begin{array}{c}\text { A qualitative } \\
\text { interpretive design } \\
\text { (Qualitative } \\
\text { open-ended } \\
\text { questionnaire and } \\
\text { focus group } \\
\text { discussions; Content } \\
\text { analysis). }\end{array}$ & $\begin{array}{l}\text { What are the factors } \\
\text { facilitating or } \\
\text { hindering local } \\
\text { students' EMI } \\
\text { learning? What are } \\
\text { their suggestions to } \\
\text { facilitate EMI } \\
\text { experiences? }\end{array}$ & Passed & Passed \\
\hline 16. & $\begin{array}{c}\text { Huang \& } \\
\text { Jhuang } \\
2015[88] \\
\text { Journal article }\end{array}$ & Taiwan & $\begin{array}{l}N=11 \\
\text { Various EMI } \\
\text { courses }\end{array}$ & $\begin{array}{l}\text { A grounded theory } \\
\text { (Classroom } \\
\text { observations and } \\
\text { semi-structured } \\
\text { interviews; Thematic } \\
\text { framework } \\
\text { approach). }\end{array}$ & $\begin{array}{l}\text { What types of } \\
\text { affordances do } \\
\text { students in these two } \\
\text { types of EMI contexts } \\
\text { perceive and accept? } \\
\text { What factors might } \\
\text { inform these } \\
\text { affordances? }\end{array}$ & Passed & Passed \\
\hline 17. & $\begin{array}{c}\text { Huang } \\
2018[84] \\
\text { Journal article }\end{array}$ & Taiwan & $\begin{array}{l}\quad N=4 \\
\text { International } \\
\text { Business, } \\
\text { Accounting }\end{array}$ & $\begin{array}{c}\text { A qualitative } \\
\text { multiple-case study } \\
\text { design } \\
\text { (semi-structured } \\
\text { interviews, learning } \\
\text { stories and class } \\
\text { observations; } \\
\text { Reconstructive } \\
\text { thematic analysis). }\end{array}$ & $\begin{array}{l}\text { What constitutes } \\
\text { learner resistance } \\
\text { during studying at } \\
\text { an EMI course? } \\
\text { Why do learners } \\
\text { construct their } \\
\text { resistance, and in } \\
\text { what ways? }\end{array}$ & Passed & Passed \\
\hline 18. & $\begin{array}{c}\text { Karakaş } \\
2017[80] \\
\text { Journal article }\end{array}$ & Turkey & $\begin{array}{l}N=20 \\
\text { Various EMI } \\
\text { courses }\end{array}$ & $\begin{array}{l}\text { Mixed methods with } \\
\text { qualitative data as a } \\
\text { primary instrument } \\
\text { (Semi-structured } \\
\text { interviews; Thematic } \\
\text { framework } \\
\text { approach). }\end{array}$ & $\begin{array}{c}\text { Do students prefer } \\
\text { NESTs, NNESTs, or } \\
\text { both for content and } \\
\text { language-focused } \\
\text { courses? } \\
\text { What factors } \\
\text { influence students' } \\
\text { preferences towards } \\
\text { NNESTs and NESTs? }\end{array}$ & Passed & Passed \\
\hline 19. & $\begin{array}{c}\text { Kuteeva } \\
2019[78] \\
\text { Journal article }\end{array}$ & Sweden & $\begin{array}{l}\quad N=5 \\
\text { Various EMI } \\
\text { courses }\end{array}$ & $\begin{array}{l}\text { A qualitative } \\
\text { interpretive design } \\
\text { (In-depth interviews; } \\
\text { Content analysis). }\end{array}$ & $\begin{array}{l}\text { What are local and } \\
\text { international } \\
\text { students' } \\
\text { conceptualisations of } \\
\text { English and } \\
\text { positioning in the } \\
\text { context of an } \\
\text { English-medium } \\
\text { university? }\end{array}$ & Passed & Passed \\
\hline 20. & $\begin{array}{l}\text { Lan } 2020 \text { [77] } \\
\text { Journal article }\end{array}$ & Taiwan & $\begin{array}{l}N=42 \\
\text { Various EMI } \\
\text { courses }\end{array}$ & $\begin{array}{l}\text { Narrative approach } \\
\text { (Semi-structured } \\
\text { interviews and } \\
\text { reflective journals; } \\
\text { Thematic framework } \\
\text { approach). }\end{array}$ & $\begin{array}{c}\text { How did the } \\
\text { participants invest in } \\
\text { non-native speaker } \\
\text { intercultural } \\
\text { interaction? } \\
\text { What were the } \\
\text { participants' } \\
\text { imagined } \\
\text { communities? }\end{array}$ & Passed & Passed \\
\hline
\end{tabular}


Table A1. Cont.

\begin{tabular}{|c|c|c|c|c|c|c|c|}
\hline \multirow[b]{2}{*}{$\#$} & \multirow[b]{2}{*}{$\begin{array}{l}\text { Author } \\
\text { Year [Ref] } \\
\text { Document } \\
\text { Type }\end{array}$} & \multirow[b]{2}{*}{ Location } & \multirow[b]{2}{*}{$\begin{array}{l}\text { Sample Size, } \\
\text { EMI Subject }\end{array}$} & \multirow[b]{2}{*}{$\begin{array}{l}\text { Design (Data } \\
\text { Collection; Data } \\
\text { Analysis) }\end{array}$} & \multirow[b]{2}{*}{$\begin{array}{l}\text { Key Research } \\
\text { Question(s) }\end{array}$} & \multicolumn{2}{|c|}{ Quality Appraisal } \\
\hline & & & & & & $\begin{array}{c}\text { CASP } \\
\text { 10-Item } \\
\text { Check List } \\
\text { [60] }\end{array}$ & $\begin{array}{c}\text { COREQ } \\
\text { 32-Item } \\
\text { Check List } \\
\text { [61] }\end{array}$ \\
\hline 21. & $\begin{array}{c}\text { Lin } 2017 \text { [73] } \\
\text { Journal article }\end{array}$ & Taiwan & $\begin{array}{c}N=82 \\
\text { Various EMI } \\
\text { courses }\end{array}$ & $\begin{array}{c}\text { Ethnographic } \\
\text { research } \\
\text { (semi-structured } \\
\text { interviews; Thematic } \\
\text { framework } \\
\text { approach). }\end{array}$ & $\begin{array}{l}\text { How do local and } \\
\text { international } \\
\text { students } \\
\text { perceive, interpret, } \\
\text { and adapt their } \\
\text { in-class behaviours in } \\
\text { multicultural EMI } \\
\text { classrooms? }\end{array}$ & Passed & Passed \\
\hline 22. & $\begin{array}{c}\text { Malavska } \\
2017[75] \\
\text { Journal article }\end{array}$ & $\begin{array}{l}\text { Latvia and } \\
\text { Russia }\end{array}$ & $\begin{array}{c}N=24 \\
\text { Various EMI } \\
\text { courses }\end{array}$ & $\begin{array}{l}\text { A qualitative } \\
\text { interpretive design } \\
\text { (Open ended } \\
\text { questionnaire, } \\
\text { Semi-structured } \\
\text { interviews; Thematic } \\
\text { framework } \\
\text { approach). }\end{array}$ & $\begin{array}{l}\text { To what extent does } \\
\text { the note-taking } \\
\text { process depend on } \\
\text { students' skills or } \\
\text { lecturers' competence } \\
\text { in delivering } \\
\text { coherent and } \\
\text { cohesive EMI } \\
\text { lectures? }\end{array}$ & Passed & Passed \\
\hline 23. & $\begin{array}{c}\text { Pitkänen et al. } \\
2013 \text { [71] } \\
\text { Journal article }\end{array}$ & Finland & $\begin{array}{c}N=60 \\
\text { Various EMI } \\
\text { courses }\end{array}$ & $\begin{array}{c}\text { A qualitative } \\
\text { interpretive design } \\
\text { (open-ended } \\
\text { electronic } \\
\text { questionnaire; } \\
\text { Content analysis). }\end{array}$ & $\begin{array}{l}\text { Why do Finnish } \\
\text { students apply to } \\
\text { study in graduate } \\
\text { EMI programmes? } \\
\text { What challenges, } \\
\text { advantages and } \\
\text { disadvantages do } \\
\text { they perceive when } \\
\text { doing so? Do they } \\
\text { feel linguistically } \\
\text { able to cope with } \\
\text { their studies? }\end{array}$ & Passed & $\begin{array}{c}\mathrm{N} / \mathrm{A} \\
\text { (No inter- } \\
\text { views/focus } \\
\text { groups used) }\end{array}$ \\
\hline 24. & $\begin{array}{c}\text { Rowland and } \\
\text { Murray } \\
2019[53] \\
\text { Journal article }\end{array}$ & Italy & $\begin{array}{c}N=18 \\
\text { Biomedical } \\
\text { sciences }\end{array}$ & $\begin{array}{l}\text { A qualitative } \\
\text { interpretive design } \\
\text { (Semi-structured } \\
\text { interviews and focus } \\
\text { group discussions; } \\
\text { Content analysis). }\end{array}$ & $\begin{array}{l}\text { What are lecturers' } \\
\text { and students' } \\
\text { perceptions } \\
\text { concerning the } \\
\text { adequacy of their } \\
\text { own and each other's } \\
\text { English language } \\
\text { proficiency? }\end{array}$ & Passed & Passed \\
\hline 25. & $\begin{array}{c}\text { Sahan } \\
2020[94] \\
\text { Journal article }\end{array}$ & Turkey & $\begin{array}{c}N=120 \\
\text { Engineering }\end{array}$ & $\begin{array}{c}\text { Classroom } \\
\text { observation (Audio } \\
\text { recording and } \\
\text { observation; } \\
\text { Thematic framework } \\
\text { approach). }\end{array}$ & $\begin{array}{l}\text { How do teachers and } \\
\text { students use } \\
\text { code-switching to } \\
\text { support content } \\
\text { learning in an ELF } \\
\text { classroom setting? }\end{array}$ & Passed & $\begin{array}{c}\mathrm{N} / \mathrm{A} \text { (No } \\
\text { inter- } \\
\text { views/focus } \\
\text { groups used) }\end{array}$ \\
\hline 26. & $\begin{array}{c}\text { Salaberri- } \\
\text { Ramiro \& } \\
\text { Sánchez-Pérez } \\
2018 \text { [64] } \\
\text { Journal article }\end{array}$ & Spain & $\begin{array}{c}N=310 \\
\text { Various EMI } \\
\text { courses }\end{array}$ & $\begin{array}{c}\text { A qualitative } \\
\text { interpretive design } \\
\text { (Open ended } \\
\text { questionnaire survey; } \\
\text { Thematic framework } \\
\text { approach). }\end{array}$ & $\begin{array}{l}\text { What are the factors } \\
\text { that motivated } \\
\text { students to } \\
\text { participate in a } \\
\text { bilingual course? } \\
\text { What changes would } \\
\text { they introduce to feel } \\
\text { more motivated to } \\
\text { participate in } \\
\text { bilingual courses in } \\
\text { the future? }\end{array}$ & Passed & $\begin{array}{c}\text { N/A } \\
\text { (No inter- } \\
\text { views/focus } \\
\text { groups used) }\end{array}$ \\
\hline
\end{tabular}


Table A1. Cont.

\begin{tabular}{|c|c|c|c|c|c|c|c|}
\hline \multirow[b]{2}{*}{$\#$} & \multirow[b]{2}{*}{$\begin{array}{c}\text { Author } \\
\text { Year [Ref] } \\
\text { Document } \\
\text { Type }\end{array}$} & \multirow[b]{2}{*}{ Location } & \multirow[b]{2}{*}{$\begin{array}{l}\text { Sample Size, } \\
\text { EMI Subject }\end{array}$} & \multirow[b]{2}{*}{$\begin{array}{c}\text { Design (Data } \\
\text { Collection; Data } \\
\text { Analysis) }\end{array}$} & \multirow[b]{2}{*}{$\begin{array}{c}\text { Key Research } \\
\text { Question(s) }\end{array}$} & \multicolumn{2}{|c|}{ Quality Appraisal } \\
\hline & & & & & & $\begin{array}{c}\text { CASP } \\
\text { 10-Item } \\
\text { Check List } \\
\text { [60] }\end{array}$ & $\begin{array}{c}\text { COREQ } \\
\text { 32-Item } \\
\text { Check List } \\
\text { [61] }\end{array}$ \\
\hline 27. & $\begin{array}{c}\text { Sibomana } \\
2016 \text { [82] } \\
\text { Journal article }\end{array}$ & South Africa & $\begin{array}{l}\quad N=21 \\
\text { Education }\end{array}$ & $\begin{array}{l}\text { A grounded theory } \\
\text { (semi-structured } \\
\text { interviews; } \\
\text { assignment tasks, } \\
\text { lecturer feedback; } \\
\text { Thematic framework } \\
\text { approach). }\end{array}$ & $\begin{array}{l}\text { What is the nature of } \\
\text { challenges faced by } \\
\text { the students? What } \\
\text { are the students' } \\
\text { coping strategies? } \\
\text { What are the effects } \\
\text { of support offered by } \\
\text { the university? }\end{array}$ & Passed & Passed \\
\hline 28. & $\begin{array}{l}\text { Somniso et al. } \\
2016 \text { [93] } \\
\text { Journal article }\end{array}$ & South Africa & $\begin{array}{c}N=9 \\
\text { Various EMI } \\
\text { courses }\end{array}$ & $\begin{array}{c}\text { A qualitative } \\
\text { interpretive design } \\
\text { (semi-structured } \\
\text { interviews; Thematic } \\
\text { framework } \\
\text { approach). }\end{array}$ & $\begin{array}{c}\text { What coping } \\
\text { strategies do students } \\
\text { from the DRC } \\
\text { employ to overcome } \\
\text { their learning } \\
\text { challenges in English } \\
\text { Medium Instruction? }\end{array}$ & Passed & Passed \\
\hline 29. & $\begin{array}{c}\text { Song \& Lin } \\
2020[96] \\
\text { Journal article }\end{array}$ & $\begin{array}{l}\text { Mainland } \\
\text { China }\end{array}$ & $\begin{array}{c}N=20 \\
\text { Various EMI } \\
\text { courses }\end{array}$ & $\begin{array}{c}\text { Ethnographic } \\
\text { research } \\
\text { (Observation and } \\
\text { interviews; Content } \\
\text { analysis). }\end{array}$ & $\begin{array}{l}\text { How do students in } \\
\text { EMI programmes } \\
\text { engage in } \\
\text { translingual practices } \\
\text { in different social } \\
\text { spaces? }\end{array}$ & Passed & Passed \\
\hline 30. & $\begin{array}{l}\text { Song } 2020 \text { [97] } \\
\text { Journal article }\end{array}$ & $\begin{array}{l}\text { Mainland } \\
\text { China }\end{array}$ & $\begin{array}{c}N=51 \\
\text { Political } \\
\text { studies }\end{array}$ & $\begin{array}{c}\text { Grounded theory } \\
\text { (Classroom } \\
\text { observations, } \\
\text { Semi-structured } \\
\text { interviews; Thematic } \\
\text { framework } \\
\text { approach). }\end{array}$ & $\begin{array}{l}\text { How has being } \\
\text { critical been } \\
\text { understood and } \\
\text { practiced in relation } \\
\text { to students' } \\
\text { intercultural } \\
\text { experiences in EMI } \\
\text { Master's degree } \\
\text { programmes? }\end{array}$ & Passed & Passed \\
\hline 31. & $\begin{array}{c}\text { Soruç \& } \\
\text { Griffiths } \\
2018 \text { [12] } \\
\text { Journal article }\end{array}$ & Turkey & $\begin{array}{c}N=39 \\
\text { International } \\
\text { Relations, } \\
\text { Psychology }\end{array}$ & $\begin{array}{c}\text { A qualitative } \\
\text { interpretive design } \\
\text { (videorecording, } \\
\text { open-ended } \\
\text { questionnaire, } \\
\text { stimulated-recall } \\
\text { interviews; Thematic } \\
\text { framework } \\
\text { approach). }\end{array}$ & $\begin{array}{c}\text { What difficulties do } \\
\text { students generally } \\
\text { have in an EMI } \\
\text { classroom? What } \\
\text { strategies do they use } \\
\text { to deal with } \\
\text { difficulties? What are } \\
\text { their views regarding } \\
\text { the EMI } \\
\text { phenomenon in } \\
\text { Turkey? }\end{array}$ & Passed & Passed \\
\hline 32. & $\begin{array}{c}\text { Studer } \\
2014[87] \\
\text { Journal article }\end{array}$ & Switzer-land & $\begin{array}{l}N=40 \\
\text { Natural } \\
\text { Resource } \\
\text { Sciences }\end{array}$ & $\begin{array}{c}\text { A qualitative } \\
\text { interpretive design } \\
\text { (Focus group } \\
\text { discussions, } \\
\text { stimulated recall } \\
\text { method; Thematic } \\
\text { framework } \\
\text { approach). }\end{array}$ & $\begin{array}{c}\text { What are } \\
\text { German-speaking } \\
\text { students' perceptions } \\
\text { of their lecturers' L2 } \\
\text { (EMI) competence in } \\
\text { the science } \\
\text { classroom? }\end{array}$ & Passed & Passed \\
\hline 33. & $\begin{array}{l}\text { Sung } 2017[74] \\
\text { Journal article }\end{array}$ & $\begin{array}{c}\text { Hong Kong } \\
\text { SAR }\end{array}$ & $\begin{array}{c}N=1 \\
\text { Various EMI } \\
\text { courses }\end{array}$ & $\begin{array}{l}\text { A narrative inquiry } \\
\text { approach (in-depth } \\
\text { interviews, elicited } \\
\text { written self-reports, } \\
\text { class observations; } \\
\text { Content analysis). }\end{array}$ & $\begin{array}{l}\text { How did the student } \\
\text { negotiate her } \\
\text { identities in the L2 } \\
\text { university classroom } \\
\text { when participating in } \\
\text { various classroom } \\
\text { oral activities? } \\
\text { How did the } \\
\text { student's classroom } \\
\text { participation change } \\
\text { over time? }\end{array}$ & Passed & Passed \\
\hline
\end{tabular}


Table A1. Cont.

\begin{tabular}{|c|c|c|c|c|c|c|c|}
\hline \multirow[b]{2}{*}{$\#$} & \multirow[b]{2}{*}{$\begin{array}{c}\text { Author } \\
\text { Year [Ref] } \\
\text { Document } \\
\text { Type }\end{array}$} & \multirow[b]{2}{*}{ Location } & \multirow[b]{2}{*}{$\begin{array}{l}\text { Sample Size, } \\
\text { EMI Subject }\end{array}$} & \multirow[b]{2}{*}{$\begin{array}{c}\text { Design (Data } \\
\text { Collection; Data } \\
\text { Analysis) }\end{array}$} & \multirow[b]{2}{*}{$\begin{array}{c}\text { Key Research } \\
\text { Question(s) }\end{array}$} & \multicolumn{2}{|c|}{ Quality Appraisal } \\
\hline & & & & & & $\begin{array}{c}\text { CASP } \\
\text { 10-Item } \\
\text { Check List } \\
\text { [60] }\end{array}$ & $\begin{array}{c}\text { COREQ } \\
\text { 32-Item } \\
\text { Check List } \\
\text { [61] }\end{array}$ \\
\hline 34. & $\begin{array}{l}\text { Tatzl } 2012[72] \\
\text { Journal article }\end{array}$ & Austria & $\begin{array}{c}N=74 \\
\text { Business, } \\
\text { Engineering }\end{array}$ & $\begin{array}{c}\text { A qualitative } \\
\text { interpretive design } \\
\text { (open-ended } \\
\text { questionnaire; } \\
\text { semi-structured } \\
\text { interviews; Content } \\
\text { analysis). }\end{array}$ & $\begin{array}{l}\text { What are Austrian } \\
\text { lecturers' and } \\
\text { students' attitudes } \\
\text { towards EMI-based } \\
\text { master's } \\
\text { programmes? What } \\
\text { are the perceived best } \\
\text { practices? How do } \\
\text { they perceive the } \\
\text { challenges of EMI } \\
\text { implementation? }\end{array}$ & Passed & Passed \\
\hline 35. & $\begin{array}{l}\text { Trent } 2008 \text { [92] } \\
\text { Journal article }\end{array}$ & $\begin{array}{c}\text { Hong Kong } \\
\text { SAR }\end{array}$ & $\begin{array}{l}\quad N=8 \\
\text { English for } \\
\text { business and } \\
\text { economics }\end{array}$ & $\begin{array}{l}\text { Ethnographic study } \\
\text { (semi-structured } \\
\text { interviews, class } \\
\text { observations and } \\
\text { recordings of } \\
\text { classroom interaction; } \\
\text { Content analysis). }\end{array}$ & $\begin{array}{l}\text { How can oral } \\
\text { classroom } \\
\text { participation by } \\
\text { undergraduate } \\
\text { students be } \\
\text { promoted in } \\
\text { English-medium } \\
\text { universities? }\end{array}$ & Passed & Passed \\
\hline 36. & $\begin{array}{c}\text { Wang \& } \\
\text { Curdt- } \\
\text { Christiansen } \\
2018[67] \\
\text { Journal article }\end{array}$ & $\begin{array}{l}\text { Mainland } \\
\text { China }\end{array}$ & $\begin{array}{c}N=37 \\
\text { Business } \\
\text { management }\end{array}$ & $\begin{array}{c}\text { Ethnographic } \\
\text { research } \\
\text { (Semi-structured } \\
\text { Interviews, } \\
\text { classroom } \\
\text { observations, and } \\
\text { collection of } \\
\text { documents; Content } \\
\text { analysis). }\end{array}$ & $\begin{array}{l}\text { What are the contexts } \\
\text { and pedagogical } \\
\text { realities that gave rise } \\
\text { to translanguaging } \\
\text { practices in EMI } \\
\text { programmes? } \\
\text { How are students as } \\
\text { individual agents } \\
\text { engaged in } \\
\text { translanguaging } \\
\text { practices? }\end{array}$ & Passed & Passed \\
\hline 37. & $\begin{array}{l}\text { Yeon } 2018 \text { [83] } \\
\text { Doctoral thesis }\end{array}$ & South Korea & $\begin{array}{c}\quad N=15 \\
\text { Various } \\
\text { EMI courses }\end{array}$ & $\begin{array}{l}\text { A qualitative } \\
\text { interpretive design } \\
\text { (semi-structured } \\
\text { in-depth interviews; } \\
\text { class observation; } \\
\text { Content analysis). }\end{array}$ & $\begin{array}{l}\text { How do learners } \\
\text { accept and act on the } \\
\text { identities, practices } \\
\text { and resources } \\
\text { available to them in } \\
\text { EMI courses at a } \\
\text { large public } \\
\text { university in South } \\
\text { Korea? }\end{array}$ & Passed & Passed \\
\hline 38. & $\begin{array}{c}\text { Yeung } \\
2020[90] \\
\text { Journal article }\end{array}$ & $\begin{array}{l}\text { Hong Kong } \\
\text { SAR }\end{array}$ & $\begin{array}{c}N=79 \\
\text { Various EMI } \\
\text { courses }\end{array}$ & $\begin{array}{c}\text { A qualitative } \\
\text { interpretive design } \\
\text { (Focus groups and } \\
\text { in-depth interviews; } \\
\text { Thematic framework } \\
\text { approach). }\end{array}$ & $\begin{array}{l}\text { Do teachers and } \\
\text { students have } \\
\text { difficulties using } \\
\text { EMI? How do they } \\
\text { cope with these } \\
\text { difficulties? }\end{array}$ & Passed & Passed \\
\hline 39. & $\begin{array}{c}\text { Yu \& Wright } \\
2017 \text { [6] } \\
\text { Journal article }\end{array}$ & $\begin{array}{l}\text { Hong Kong } \\
\text { SAR }\end{array}$ & $\begin{array}{c}N=124 \\
\text { Various EMI } \\
\text { courses }\end{array}$ & $\begin{array}{c}\text { A qualitative } \\
\text { interpretive design } \\
\text { (Focus group } \\
\text { interviews; Content } \\
\text { analysis). }\end{array}$ & $\begin{array}{c}\text { How do local, } \\
\text { Mainland Chinese } \\
\text { and international } \\
\text { students perceive the } \\
\text { main } \\
\text { challenges to } \\
\text { academic } \\
\text { adaptation? }\end{array}$ & Passed & Passed \\
\hline 40. & $\begin{array}{c}\text { Yu et al. } \\
2020[13] \\
\text { Journal article }\end{array}$ & Macao SAR & $\begin{array}{c}N=14 \\
\text { Various EMI } \\
\text { courses }\end{array}$ & $\begin{array}{c}\text { A qualitative } \\
\text { interpretive design } \\
\text { (Semi-structured } \\
\text { interviews and } \\
\text { reflective journals; } \\
\text { Thematic framework } \\
\text { approach). }\end{array}$ & $\begin{array}{l}\text { What are the } \\
\text { perceived benefits } \\
\text { and losses of } \\
\text { Mainland Chinese } \\
\text { students during EMI } \\
\text { learning? }\end{array}$ & Passed & Passed \\
\hline
\end{tabular}




\section{References}

1. Marinoni, G.; de Wit, H. Internationalization of Higher Education in the New Political Climate. Inside High. Ed. Available online: https://www.insidehighered.com/blogs/world-view/internationalization-higher-education-new-political-climate (accessed on 3 March 2021).

2. Dearden, J. English as a Medium of Instruction-A Growing Global Phenomenon; British Council: London, UK, 2015; Available online: https:/ / ora.ox.ac.uk/objects/uuid:4f72cdf8-b2eb-4d41-a785-4a283bf6caaa (accessed on 13 January 2021).

3. Mueller Iyobe, B.; Li, J. Factors for Success and Sustainability of an Elective English-Medium Instruction Program. In EnglishMedium Instruction in Japanese Higher Education; Bradford, A., Brown, H., Eds.; Multilingual Matters: Bristol, UK, 2017. [CrossRef]

4. Kim, Y. The Value of Interactive Polling and Intrinsic Motivation When Using English as a Medium of Instruction. Sustainability 2020, 12, 1332. [CrossRef]

5. Rakhshandehroo, M.; Ivanova, P. International student satisfaction at English-medium graduate programs in Japan. High. Educ. 2019, 79, 39-54. [CrossRef]

6. Yu, B.; Wright, E. Academic adaptation amid internationalisation: The challenges for local, mainland Chinese, and international students at Hong Kong's universities. Tert. Educ. Manag. 2017, 23, 347-360. [CrossRef]

7. Macaro, E. English Medium Instruction. Content and Language in Policy and Practice; Oxford University Press: Oxford, UK, 2018.

8. Chapple, J. Teaching in English Is Not Necessarily the Teaching of English. Int. Educ. Stud. 2015, 8, 1-13. [CrossRef]

9. Macaro, E.; Curle, S.; Pun, J.; An, J.; Dearden, J. A systematic review of English medium instruction in higher education. Lang. Teach. 2017, 51, 36-76. [CrossRef]

10. Curle, S.; Yuksel, D.; Soruç, A.; Altay, M. Predictors of English Medium Instruction academic success: English proficiency versus first language medium. System 2020, 95, 102378. [CrossRef]

11. Rose, H.; Curle, S.; Aizawa, I.; Thompson, G. What drives success in English medium taught courses? The interplay between language proficiency, academic skills, and motivation. Stud. High. Educ. 2019, 45, 2149-2161. [CrossRef]

12. Soruç, A.; Griffiths, C. English as a medium of instruction: Students' strategies. ELT J. 2017, 72, 38-48. [CrossRef]

13. Yu, S.; Wang, Y.; Jiang, L.; Wang, B. Coping with EMI (English as a medium of instruction): Mainland China students' strategies at a university in Macau. Innov. Educ. Teach. Int. 2020, 58, 462-472. [CrossRef]

14. Aizawa, I.; Rose, H.; Thompson, G.; Curle, S. Beyond the threshold: Exploring English language proficiency, linguistic challenges, and academic language skills of Japanese students in an English medium instruction programme. Lang. Teach. Res. 2020, 136216882096551. [CrossRef]

15. Macaro, E. Exploring the role of language in English medium instruction. Int. J. Biling. Educ. Biling. 2019, 23, 263-276. [CrossRef]

16. Galloway, N.; Numajiri, T.; Rees, N. The 'internationalisation', or 'Englishisation', of higher education in East Asia. High. Educ. 2020, 80, 395-414. [CrossRef]

17. Wanphet, P.; Tantawy, N. Effectiveness of the policy of English as a medium of instruction: Perspectives and outcomes from the instructors and students of university science courses at a university in the UAE. Educ. Res. Policy Pract. 2017, 17, 145-172. [CrossRef]

18. Chickering, A.W.; Gamson, Z.F. Seven Principles for Good Practice in Undergraduate Education. Wingspread J. 1987, 9, 1-10.

19. Sharkey, S.; Weimer, M. Learner-Centered Teaching: Five Key Changes to Practice. Teach. Sociol. 2003, 31, 251. [CrossRef]

20. Merrill, M.D. First principles of instruction. Educ. Technol. Res. Dev. 2002, 50, 43-59. [CrossRef]

21. Ramsden, P. Learning to Teach in Higher Education, 2nd ed.; Routledge Falmer: New York, NY, USA, 2003.

22. Biggs, J.; Tang, C. Using Constructive Alignment in Outcomes-Based Teaching and Learning Teaching for Quality Learning at University, 3rd ed.; Open University Press: Berkshire, UK, 2007.

23. Schweisfurth, M. Learner-centred pedagogy: Towards a post-2015 agenda for teaching and learning. Int. J. Educ. Dev. 2015, 40, 259-266. [CrossRef]

24. Li, L. Student perceptions of the teaching of principles of management using English-medium instruction. J. Educ. Bus. 2019, 95, 115-120. [CrossRef]

25. Macaro, E.; Tian, L.; Chu, L. First and second language use in English medium instruction contexts. Lang. Teach. Res. 2018, 24, 382-402. [CrossRef]

26. Kim, J.-Y.; Choi, J.; Tatar, B. English-Medium Instruction and Intercultural Sensitivity: A Korean Case Study. J. Stud. Int. Educ. 2017, 21, 467-482. [CrossRef]

27. Kim, V.; Kim, J. Roles of Teacher Feedback in Promoting Effective English-Medium Instruction of a Business Subject. J. Asiat. 2020, 17, 889-905. [CrossRef]

28. Richards, J.C.; Pun, J. A Typology of English-Medium Instruction. RELC J. 2021, 003368822096858. [CrossRef]

29. Bradford, A. Toward a Typology of Implementation Challenges Facing English-Medium Instruction in Higher Education. J. Stud. Int. Educ. 2016, 20, 339-356. [CrossRef]

30. Sahan, K.; Rose, H.; Macaro, E. Models of EMI pedagogies: At the interface of language use and interaction. System 2021, 101, 102616. [CrossRef]

31. Thompson, G.; Aizawa, I.; Curle, S.; Rose, H. Exploring the role of self-efficacy beliefs and learner success in English medium instruction. Int. J. Biling. Educ. Biling. 2019, 1-14. [CrossRef] 
32. Williams, D.; A Systematic Review of EMI and Implications for the South Korean HE Context. ELT World Online 2015, 1-23. Available online: https:/ / tinyurl.com/4xtmvnzp (accessed on 16 March 2021).

33. Kremer, M.; Valcke, M. Teaching and learning in English in higher education: A literature review. In Proceedings of the 6th International Conference on Education and New Learning Technologies (EDULEARN), Barcelona, Spain, 7-9 July 2014; pp. 1430-1441. Available online: http:/ /hdl.handle.net/1854/LU-5818549 (accessed on 3 March 2021).

34. Rocha, Á.; Gonçalves, M.J.A.; da Silva, A.F.; Teixeira, S.; Silva, R. Leadership Challenges in the Context of University 4.0. A Thematic Synthesis Literature Review. Comput. Math. Organ. Theory 2021. [CrossRef]

35. Baeten, M.; Dochy, F.; Struyven, K. Using students' motivational and learning profiles in investigating their perceptions and achievement in case-based and lecture-based learning environments. Educ. Stud. 2012, 38, 491-506. [CrossRef]

36. Wright, G. Student-Centred Learning in Higher Education. Int. J. Teach. Learn. High. Educ. 2011, $23,92-97$.

37. Paris, C.; Combs, B. Lived meanings: What teachers mean when they say they are learner-centred. Teach. Teach. Theory Pract. 2006, 12, 571-592. [CrossRef]

38. Jacobs, G.M.; Renandya, W.A.; Power, M. Simple, Powerful Strategies for Student Centered Learning; Springer International Publishin: Berlin/Heidelberg, Germany, 2016.

39. Sahan, K. Implementing English-medium instruction. Aust. Rev. Appl. Linguist. 2021, 44, 129-153. [CrossRef]

40. Bolton, K.; Botha, W.; Bacon-Shone, J. English-medium instruction in Singapore higher education: Policy, realities and challenges. J. Multiling. Multicult. Dev. 2017, 38, 913-930. [CrossRef]

41. Wallace, A.; Spiliotopoulos, V.; Ilieva, R. CLIL Collaborations in Higher Education: A Critical Perspective. Engl. Teach. Learn. 2020, 44, 127-148. [CrossRef]

42. Macaro, E.; Tian, L. Developing EMI teachers through a collaborative research model. J. Multiling. Multicult. Dev. 2020, 1-16. [CrossRef]

43. Arnó-Macià, E.; Aguilar-Pérez, M.; Tatzl, D. Engineering students' perceptions of the role of ESP courses in internationalized universities. Engl. Specif. Purp. 2020, 58, 58-74. [CrossRef]

44. Muguruza, B.; Cenoz, J.; Gorter, D. Implementing translanguaging pedagogies in an English medium instruction course. Int. J. Multiling. 2020, 1-16. [CrossRef]

45. Fang, F.; Liu, Y. 'Using all English is not always meaningful': Stakeholders' perspectives on the use of and attitudes towards translanguaging at a Chinese university. Lingua 2020, 247, 102959. [CrossRef]

46. Moore, E. Conceptualising multilingual higher education in policies, pedagogical designs and classroom practices. Lang. Cult. Curric. 2016, 29, 22-39. [CrossRef]

47. Macaro, E.; Sahan, K.; Rose, H. The profiles of English medium instruction teachers in higher education. Int. J. Appl. Linguist. 2021, 31, 458-474. [CrossRef]

48. Gustafsson, H. Capturing EMI teachers' linguistic needs: A usage-based perspective. Int. J. Biling. Educ. Biling. 2018, 23, 1071-1082. [CrossRef]

49. Wang, Y.; Yu, S.; Shao, Y. The experiences of Chinese mainland students with English-medium instruction in a Macau University. Educ. Stud. 2017, 44, 357-360. [CrossRef]

50. Yu, B.; Zhang, K. 'It's more foreign than a foreign country': Adaptation and experience of Mainland Chinese students in Hong Kong. Tert. Educ. Manag. 2016, 22, 300-315. [CrossRef]

51. Qiu, X.; Fang, C. Creating an effective English-Medium Instruction (EMI) classroom: Chinese undergraduate students' perceptions of native and non-native English-speaking content teachers and their experiences. Int. J. Biling. Educ. Biling. 2019, 1-15. [CrossRef]

52. Hua, T.-L. Understanding the Learning Challenges of English-Medium Instruction Learners and Ways to Facilitate Their Learning: A Case Study of Taiwan Psychology Students' Perspectives. Lat. Am. J. Content Lang. Integr. Learn. 2020, 12, 321-340. [CrossRef]

53. Rowland, L.; Murray, N. Finding their feet: Lecturers' and students' perceptions of English as a medium of instruction in a recently-implemented Master's programme at an Italian university. J. Multiling. Multicult. Dev. 2019, 41, 1-14. [CrossRef]

54. Goodman, B.A.; Montgomery, D.P. "Now I always try to stick to the point": Socialization to and from genre knowledge in an English-medium university in Kazakhstan. J. Engl. Acad. Purp. 2020, 48, 100913. [CrossRef]

55. Chung, J.H.J. "We Participate, Silently": Explicating Thai University Students' Perceptions of Their Classroom Participation and Communication. Qual. Res. Educ. 2021, 10, 62-87. [CrossRef]

56. Melnyk, V.; Mikhnenko, G. International Students' Perception of Teaching Microbiology, Virology and Immunology at Medical Universities in Ukraine. Adv. Educ. 2020, 7, 56-65. [CrossRef]

57. Dearden, J.; Spain, T. A Definition of an EMI Course. In EMI Enhancement Plan 2021-2026, the Program on Bilingual Education for Students in College (BEST); Ministry of Education Taiwan \& British Council, Ed.; Ministry of Education Taiwan: Taipei, Taiwan, 2021; p. 5. Available online: https:/ / www.researchgate.net/project/Taiwan-Ministry-of-Education-BEST-programme (accessed on 15 August 2021).

58. Tong, A.; Flemming, K.; McInnes, E.; Oliver, S.; Craig, J. Enhancing transparency in reporting the synthesis of qualitative research: ENTREQ. BMC Med. Res. Methodol. 2012, 12, 181. [CrossRef]

59. Ong, M.; Jaumot-Pascual, N.; Ko, L.T. Research literature on women of color in undergraduate engineering education: A systematic thematic synthesis. J. Eng. Educ. 2020, 109, 581-615. [CrossRef]

60. Critical Appraisal Skills Programme. CASP Qualitative Studies Checklist. 2018. Available online: https://casp-uk.b-cdn.net/wpcontent/uploads/2018/03/CASP-Qualitative-Checklist-2018_fillable_form.pdf (accessed on 12 January 2021). 
61. Tong, A.; Sainsbury, P.; Craig, J. Consolidated criteria for reporting qualitative research (COREQ): A 32-item checklist for interviews and focus groups. Int. J. Qual. Health Care 2007, 19, 349-357. [CrossRef]

62. Page, M.J.; McKenzie, J.E.; Bossuyt, P.M.; Boutron, I.; Hoffmann, T.C.; Mulrow, C.D.; Shamseer, L.; Tetzlaff, J.M.; Akl, E.A.; Brennan, S.E.; et al. The PRISMA 2020 statement: An updated guideline for reporting systematic reviews. BMJ 2021, 372, n71. [CrossRef] [PubMed]

63. Thomas, J.; Harden, A. Methods for the thematic synthesis of qualitative research in systematic reviews. BMC Med. Res. Methodol. 2008, 8, 45. [CrossRef] [PubMed]

64. Ramiro, M.S.S. Motivations of Higher Education Students to Enrol in Bilingual Courses. Porta Ling. Int. J. Didact. For. Lang. 2018, 3, 61-74. [CrossRef]

65. Ali, H.I.H. Omani Students' Coping Strategies in an English Medium Engineering Programme. Arab. World Engl. J. 2020, 11, 361-382. [CrossRef]

66. Fareed, M.; Ashraf, A.; Mushtaque, S. Medium of Instruction in Education: Perceptions of Teachers and Students from Pakistani School, College and University. FWU J. Soc. Sci. 2019, 13, 134-143.

67. Wang, W.; Curdt-Christiansen, X.L. Translanguaging in a Chinese-English bilingual education programme: A universityclassroom ethnography. Int. J. Biling. Educ. Biling. 2018, 22, 322-337. [CrossRef]

68. Doiz, A.; Lasagabaster, D. Teachers' and Students' Second Language Motivational Self System in English-Medium Instruction: A Qualitative Approach. TESOL Q. 2018, 52, 657-679. [CrossRef]

69. Henry, A.; Goddard, A. Bicultural or Hybrid? The Second Language Identities of Students on an English-Mediated University Program in Sweden. J. Lang. Identity Educ. 2015, 14, 255-274. [CrossRef]

70. Doiz, A.; Lasagabaster, D.; Sierra, J. Globalisation, internationalisation, multilingualism and linguistic strains in higher education. Stud. High. Educ. 2013, 38, 1407-1421. [CrossRef]

71. Pitkänen, K.K.; Siddall, R.; Lehtonen, T. The linguistic landscape of international students in English-medium Master's programmes at the University of Helsinki: Student perceptions on the use of English and plurilingualism. Lang. Learn. High. Educ. 2013, 2. [CrossRef]

72. Tatzl, D. English-medium masters' programmes at an Austrian university of applied sciences: Attitudes, experiences and challenges. J. Engl. Acad. Purp. 2011, 10, 252-270. [CrossRef]

73. Lin, S. To speak or not to speak in the new Taiwanese university: Class participation and identity construction in linguistically and culturally diverse graduate classrooms. Lang. Intercult. Commun. 2017, 18, 184-203. [CrossRef]

74. Sung, C.C.M. Understanding classroom participation and identity negotiation: An undergraduate student's L2 learning experiences in an English-medium university in Hong Kong. Appl. Linguist. Rev. 2017, 8, 375-399. [CrossRef]

75. Malavska, V. Problems Students Encounter with Note-Taking in English-Medium Instruction. BJELLC 2017, 7, 121-138.

76. Hamid, M.O.; Jahan, I.; Islam, M. Medium of instruction policies and language practices, ideologies and institutional divides: Voices of teachers and students in a private university in Bangladesh. Curr. Issues Lang. Plan. 2013, 14, 144-163. [CrossRef]

77. Lan, S.-W. Intercultural Interaction in English: Taiwanese University Students' Investment and Resistance in Culturally Mixed Groups. SAGE Open 2020, 10, 215824402094186. [CrossRef]

78. Kuteeva, M. Revisiting the 'E' in EMI: Students' perceptions of standard English, lingua franca and translingual practices. Int. J. Biling. Educ. Biling. 2019, 23, 287-300. [CrossRef]

79. Chalapati, S.; Leung, R.; Chalapati, N. Exploring factors affecting first-year students' learning experiences: A case study of a private university in Taiwan. Stud. Success 2018, 9, 25-39. [CrossRef]

80. Karakaş, A. Teacher Preferences in Content and Language-focused Courses in Higher Education: The Case of Turkish EMI Students. J. Lang. Teach. Learn. 2017, 7, 127-145.

81. Ding, F.; Stapleton, P. Walking like a toddler: Students' autonomy development in English during cross-border transitions. System 2016, 59, 12-28. [CrossRef]

82. Sibomana, E. 'We know what to say, we know what to write, but we don't know how': The challenges of becoming academically literate in a new linguistic and socio-cultural space. Educ. Chang. 2016, 20, 1-22. [CrossRef]

83. Yeon, S. Globalization in the Classroom: A Qualitative Study on Teaching and Learning in English-Medium Courses at a University in South Korea. Ph.D. Dissertation, University of Washington, Seattle, WA, USA, 2018. Available online: https://digital.lib. washington.edu/researchworks/bitstream/handle/1773/42925/Yeon_washington_0250E_19015.pdf?sequence=1 (accessed on 26 January 2021).

84. Huang, Y.-P. Learner Resistance to English-medium instruction practices: A qualitative case study. Teach. High. Educ. 2018, 23, 435-449. [CrossRef]

85. Hino, N. The Significance of EMI for the Learning of EIL in Higher Education: Four Cases from Japan. In Successful Family Language Policy; Springer International Publishing: Berlin/Heidelberg, Germany, 2017; pp. 115-131.

86. He, J.-J.; Chiang, S.-Y. Challenges to English-medium instruction (EMI) for international students in China: A learners' perspective. Engl. Today 2016, 32, 63-67. [CrossRef]

87. Studer, P. Coping with English: Students' perceptions of their teachers' linguistic competence in undergraduate science teaching. Int. J. Appl. Linguist. 2015, 25, 183-201. [CrossRef]

88. Huang, Y.-P.; Jhuang, W.-T. Affordance of English-Medium Instruction Contexts in Taiwan. Taiwan J. TESOL 2015, 12, 1-35. 
89. Galloway, N.; Ruegg, R. The provision of student support on English Medium Instruction programmes in Japan and China. J. Engl. Acad. Purp. 2020, 45, 100846. [CrossRef]

90. Yeung, M. The Use of English As a Medium of Instruction in Higher Education in Post-Colonial Hong Kong-Perceived Realities And Issues. Taiwan J. TESOL 2020, 17, 39-64. [CrossRef]

91. Alhassan, A.; Ali, N.A.; Ali, H.I.H. EFL students' challenges in English-medium business programmes: Perspectives from students and content teachers. Cogent Educ. 2021, 8, 1888671. [CrossRef]

92. Trent, J. Towards a Pedagogical Framework for Participatory Learning in EAP. J. Asia TEFL 2008, 5, 1-25.

93. Somniso, M.; Cekiso, M.; Tshotsho, B.; Lydy, M. Exploring the Coping Strategies Employed by Congolese Students in a South African University. Int. J. Educ. Sci. 2016, 12, 212-218. [CrossRef]

94. Sahan, K. ELF interactions in English-medium engineering classrooms. ELT J. 2020, 74, 418-427. [CrossRef]

95. Han, Y.; Li, W.; Bao, M.; Cao, X. An Investigation of the Experiences of Working with Multilingual International Students among Local Students and Faculty Members in Chinese Universities. Sustainability 2020, 12, 6419. [CrossRef]

96. Song, Y.; Lin, A.M.Y. Translingual practices at a Shanghai university. World Engl. 2020, 39, 249-262. [CrossRef]

97. Song, Y. Forming critical selves through lived experiences of interculturality in an internationalizing university in China. Asia Pac. J. Educ. 2020, 40, 299-314. [CrossRef]

98. Baker, W.; Fang, F. (Gabriel) 'So maybe I'm a global citizen': Developing intercultural citizenship in English medium education. Lang. Cult. Curric. 2021, 34, 1-17. [CrossRef]

99. Goodman, B.; Tastanbek, S. Making the Shift from a Codeswitching to a Translanguaging Lens in English Language Teacher Education. TESOL Q. 2021, 55, 29-53. [CrossRef]

100. Wei, L. Moment Analysis and translanguaging space: Discursive construction of identities by multilingual Chinese youth in Britain. J. Pragmat. 2011, 43, 1222-1235. [CrossRef]

101. Tran, T.T.T. Key components of teaching from students' perspectives- Some positive shifts in Vietnamese higher education. J. Furth. High. Educ. 2021, 45, 943-957. [CrossRef]

102. Corrales, K.A.; Rey, L.A.P.; Escamilla, N.S. Is EMI Enough? Perceptions from University Professors and Students. Lat. Am. J. Content Lang. Integr. Learn. 2016, 9, 318-344. [CrossRef]

103. Wan, Z.; Gao, X. English or Chinese as medium of instruction? International students' perceptions and practices in Chinese universities. Engl. Today 2019, 36, 37-44. [CrossRef]

104. Ismailov, M.; Laurier, J. We are in the "breakout room." Now what? An e-portfolio study of virtual team processes involving undergraduate online learners. E-Learn. Digit. Media 2021, 204275302110397. [CrossRef]

105. Ismailov, M. Conceptualizing an inquiry-based lingua-cultural learning through telecollaborative exchanges. F1000Research 2021, 10, 677. [CrossRef]

106. Ismailov, M. Virtual exchanges in an inquiry-based learning environment: Effects on intra-cultural awareness and intercultural communicative competence. Cogent Educ. 2021, 8, 8. [CrossRef]

107. Chiu, T.K. Digital support for student engagement in blended learning based on self-determination theory. Comput. Hum. Behav. 2021, 124, 106909. [CrossRef]

108. Chiu, T.K.F. Applying the self-determination theory (SDT) to explain student engagement in online learning during the COVID-19 pandemic. J. Res. Technol. Educ. 2021, 1-17. [CrossRef]

109. Chiu, T.K.; Hew, T.K. Factors influencing peer learning and performance in MOOC asynchronous online discussion forum. Australas. J. Educ. Technol. 2018, 34, 16-28. [CrossRef]

110. Ismailov, M. Designing motivating online assignments and telecollaborative tasks in the time of a pandemic: Evidence from a post-course survey study in Japan. In Culture in the Communication Age: Proceedings of Society for Information Technology and Teacher Education (SITE); Langran, E., Archambault, L., Eds.; SITE: Waynesville, NC, USA, 2021; pp. 600-609. [CrossRef]

111. Chell, G.; Mikkilä-Erdmann, M.; Iiskala, T.; Dillon, A. A comparative study of academic literacy in English medium instruction programs in UAE and Finland. Issues Educ. Res. 2021, 31, 56-75.

112. Denman, C.J.; Al-Mahrooqi, R. English Medium Instruction, Arabic and Identity in Oman's Higher Education Institutions: Teacher and Student Attitudes. Engl. Teach. Learn. 2019, 43, 317-335. [CrossRef]

113. Li, C.; Ruan, Z. Changes in beliefs about language learning among Chinese EAP learners in an EMI context in Mainland China: A socio-cultural perspective. System 2015, 55, 43-52. [CrossRef]

114. Chiu, T.K.F. Student engagement in K-12 online learning amid COVID-19: A qualitative approach from a self-determination theory perspective. Interact. Learn. Environ. 2021, 1-14. [CrossRef]

115. Jin, J. Students' silence and identity in small group interactions. Educ. Stud. 2017, 43, 328-342. [CrossRef]

116. Sabaté-Dalmau, M. The Englishisation of higher education in Catalonia: A critical sociolinguistic ethnographic approach to the students' perspectives. Lang. Cult. Curric. 2016, 29, 263-285. [CrossRef]

117. Brown, K.L. From teacher-centered to learner-centered curriculum: Improving learning in diverse classrooms. Education 2003, 124, 49-54.

118. Moate, R.M.; Cox, J.A. Learner-Centered Pedagogy: Considerations for Application in a Didactic Course. Prof. Couns. 2015, 5, 379-389. [CrossRef]

119. Bain, K. What the Best College Teachers Do; Harvard University Press: Cambridge, MA, USA, 2004. 
120. Diseth, Åge Students' Evaluation of Teaching, Approaches to Learning, and Academic Achievement. Scand. J. Educ. Res. 2007, 51, 185-204. [CrossRef]

121. Morell, T. Multimodal competence and effective interactive lecturing. System 2018, 77, 70-79. [CrossRef]

122. Ismailov, M.; Ono, Y. Assignment Design and its Effects on Japanese College Freshmen's Motivation in L2 Emergency Online Courses: A Qualitative Study. Asia Pac. Educ. Res. 2021, 30, 263-278. [CrossRef]

123. Boudreau, P.; Mackenzie, S.H.; Hodge, K. Flow states in adventure recreation: A systematic review and thematic synthesis. Psychol. Sport Exerc. 2020, 46, 101611. [CrossRef]

124. Naidoo, N.; Nguyen, V.T.; Ravaud, P.; Young, B.; Amiel, P.; Schanté, D.; Clarke, M.; Boutron, I. The research burden of randomized controlled trial participation: A systematic thematic synthesis of qualitative evidence. BMC Med. 2020, 18, 1-11. [CrossRef] 